\title{
Coordinatively labile 18-electron arene ruthenium iminophosphonamide complexes
}

\author{
lana S. Sinopalnikova, ${ }^{[a, b]}$ Tat'yana A. Peganova, ${ }^{[a]}$ Valentin V. Novikov, ${ }^{[a]}$ Ivan V. Fedyanin, ${ }^{[a]}$ Oleg A. \\ Filippov, ${ }^{[a]}$ Natalia V. Belkova, ${ }^{[a]}$ Elena S. Shubina, ${ }^{\left[{ }^{[a]}\right.}$ Rinaldo Poli, ${ }^{[b, c]}$ Alexander M. Kalsin ${ }^{*[a]}$
}

\begin{abstract}
The thermodynamics of chloride dissociation from the $18 \overline{\mathrm{e}}$ arene ruthenium iminophosphonamides $\left[\left(\eta^{6}\right.\right.$-arene $\left.) \operatorname{RuCl}\left\{\left(\mathrm{R}^{\prime} \mathrm{N}\right)_{2} \mathrm{PR}_{2}\right\}\right]$ (1a-d) (previously known systems with arene $=\mathrm{C}_{6} \mathrm{Me}_{6}, \mathrm{R}=\mathrm{Ph}, \mathrm{R}^{\prime}=$ $p$-Tol $(\mathbf{a}) ; \mathrm{R}=\mathrm{Et}, \mathrm{R}^{\prime}=p$-Tol (b); $\mathrm{R}=\mathrm{Ph}, \mathrm{R}^{\prime}=\mathrm{Me}(\mathbf{c}) ;$ and new ones with arene $=p$-cymene, $\mathrm{R}=\mathrm{Ph}, \mathrm{R}^{\prime}=p$-Tol $\left.(\mathbf{d})\right)$ has been assessed in both polar and apolar solvents, using variable-temperature UV-visible, NMR and $2 \mathrm{D}$ EXSY ${ }^{1} \mathrm{H}$ NMR methods, highlighting the NPN ligand influence on the equilibrium parameters. The dissociation enthalpy $\Delta H_{\mathrm{d}}$ decreases upon increasing the electron-donating ability of the $\mathrm{N}$-, P-substituents $(\mathbf{1 a}, \mathbf{1 d}>\mathbf{1 b}>\mathbf{1 c})$ and the solvent polarity, resulting in the exothermic spontaneous dissociation of $1 \mathrm{c}$ in polar solvents. The coordination of neutral ligands ( $\mathrm{MeCN}$, pyridine, $\mathrm{CO}$ ) to the corresponding $16 \bar{e}$ complexes $\left[\left(\eta^{6} \text {-arene }\right) \operatorname{Ru}\left\{\left(\mathrm{R}^{\prime} \mathrm{N}\right)_{2} \mathrm{PR}_{2}\right\}\right]^{+}\left(\mathrm{PF}_{6}^{-}\right)(2 \mathrm{a}$ d) is reversible; the stability of the $\mathbf{2 \cdot} \mathrm{L}$ adducts depends on the $\mathrm{L} \pi$ accepting ability. Carbonylation of $\mathbf{2 a}$ and $\mathbf{2} \mathbf{d}$ results rare examples of cationic arene ruthenium carbonyl complexes $(\mathbf{3 a}, \mathbf{3 d})$, while the monocarbonyl adduct derived from $\mathbf{2 c}$ reacts further with a second $\mathrm{CO}$ molecule, rapidly converting to the carbonyl-carbamoyl complex 3c, where one $\mathrm{CO}$ molecule is inserted into the $\mathrm{Ru}-\mathrm{N}$ bond. The new complexes $\mathbf{1 d}, \mathbf{2 d}, \mathbf{3 a}, \mathbf{3 c}$ and $\mathbf{3 d}$ were isolated and structurally characterized.
\end{abstract}

\section{Introduction}

Coordinatively unsaturated complexes are often considered as intermediates in various metal-catalyzed organic transformations. Generally the stability of these species correlates with their activity in catalysis, i.e. the more unsaturated species are more reactive, however at the expense of selectivity. Ruthenium complexes are known to catalyze numerous organic reactions ${ }^{[1]}$ of substrates bearing various functional groups, to which a catalyst must be tolerant. The reactivity of the unsaturated species thus should be fine-tuned by reducing the electrophilicity of the ruthenium center with the ligand environment. Ligands

[a] Ms. Iana S. Sinopalnikova, Dr. Tat'yana A. Peganova, Dr. Valentin V. Novikov, Dr. Ivan V. Fedyanin, Dr. Oleg A. Filippov, Prof. Natalia V. Belkova, Prof. Elena S. Shubina, and Dr. Alexander M. Kalsin* A.N. Nesmeyanov Institute of Organoelement Compounds Russian Academy of Sciences 28 Vavilov str., 119991 Moscow, Russia E-mail:kalsin@ineos.ac.ru

[b] Ms. Iana S. Sinopalnikova and Prof. Rinaldo Poli Laboratoire de Chimie de Coordination CNRS Université de Toulouse, UPS, INPT 205 Route de Narbonne, 31077 Toulouse Cedex 4, France

[c] Prof. Rinaldo Poli Institut Universitaire de France

1, rue Descartes, 75231 Paris Cedex 05, France

Supporting information for this article is given via a link at the end of the document having extra lone pair at the coordinated heteroatom are capable to partially compensate the electron deficiency of the metal via $\pi$ donation. ${ }^{[2]} \mathrm{O}$ - and $\mathrm{N}$-ligands usually provide significantly greater stabilization than halides, e.g. following the order $\mathrm{OSiMe}_{2} \mathrm{Ph}>$ $\mathrm{NHPh}>\mathrm{OSiPh}_{3}>\mathrm{OCH}_{2} \mathrm{CF}_{3}>>\mathrm{Cl}>\mathrm{Br}>\mathrm{I}$ for half-sandwich $\left[\mathrm{Cp}{ }^{*} \mathrm{Ru}(\mathrm{X})\left(\mathrm{PR}_{3}\right)\right]$ complexes. ${ }^{\left[{ }^{3]}\right.}$ Among the chelating anionic $K^{2}$. $\mathrm{N}, \mathrm{N}$-ligands, strongly electron-donating $\beta$-diketiminate and zwitterionic bis(imidazoline-2-imine) ligands were found to generate either $18 \bar{e}$ complexes with weakened $\mathrm{Ru}-\mathrm{Cl}$ bonds, ${ }^{[4-6]}$ or very stable $16 \bar{e}$ half-sandwich ruthenium complexes that do not coordinate the chloride ion at all. ${ }^{[7,8]}$ The $\pi$-donation of the lone electronic pairs at the nitrogen atoms in ruthenium amidinates is limited because of symmetry reasons; it occurs only in the unfavorable conformation with a bent metallacycle and thus the stabilization effect is less pronounced. ${ }^{[9-13]}$ We have recently proposed that structurally similar iminophosphonamide ligands

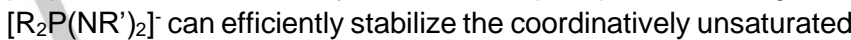
ruthenium complexes, thanks to their zwitterionic structure ${ }^{[14]}$ and therefore to the absence of symmetry restrictions for $\pi$ donation. ${ }^{[15]}$ The observation of elongated $\mathrm{Ru}-\mathrm{Cl}$ bonds (2.44$2.45 \AA)$ in $18 \bar{e}$ complexes $\left[\left(\mathrm{C}_{6} \mathrm{Me}_{6}\right) \mathrm{RuCl}\left\{(\mathrm{RN})_{2} \mathrm{PR}_{2}\right\}\right]$ and shortened $\mathrm{Ru}-\mathrm{N}$ bonds (average 2.01-2.04 $\AA$ ) in the corresponding $16 \overline{\mathrm{e}}$ complexes $\left[\left(\mathrm{C}_{6} \mathrm{Me}_{6}\right) \mathrm{Ru}\left\{(\mathrm{RN})_{2} \mathrm{PR}_{2}{ }_{2}\right]^{+}\left(\mathrm{X}^{-}\right)\right.$ supports this hypothesis. ${ }^{[15]}$ In 1998 Parsons et al. reported the first $16 \overline{\mathrm{e}}$ ruthenium iminophosphonamide complex $[(p-$ Cymene) Ru $\left.\left\{\left({ }^{(} \mathrm{PrN}\right)_{2} \mathrm{PPh}\left(\mathrm{NH}^{\mathrm{i} P r}\right)\right\}\right]\left(\mathrm{BPh}_{4}\right)$ to be extremely stable and inert to the addition of $\mathrm{Cl}^{-}, \mathrm{PPh}_{3}$ and $\mathrm{P}(\mathrm{OEt})_{3}$; even the $\mathrm{CO}$ adduct could not be isolated due to intrinsic instability. ${ }^{[16]}$ Since then, no $18 \bar{e}$ cationic NPN complexes [(arene)Ru(L) $\left.\left\{(\mathrm{RN})_{2} \mathrm{PR}_{2}{ }_{2}\right\}\right]^{+}$ could be isolated, suggesting that the $\sigma, \pi$-donor character of the NPN ligand is too strong to allow stability for such adducts.

Here we report a comprehensive quantitative exploration of reversible coordination of neutral ligands with various $\pi$-acceptor capabilities ( $\mathrm{MeCN}$, pyridine and $\mathrm{CO}$ ) to cationic $16 \overline{\mathrm{e}}$ arene ruthenium iminophosphonamides $2 \mathbf{a}-\mathbf{d}$, and the chloride dissociation from the $18 \bar{e}$ complexes 1a-d (Chart 1), aiming to determine the influence of the arene nature and of the $\mathrm{N}-, \mathrm{P}$ substituents in the NPN-ligand on the thermodynamics of ligand coordination/dissociation. These data on the coordination behavior of ruthenium iminophosphonamides are particularly important in view of their potential use in catalysis.
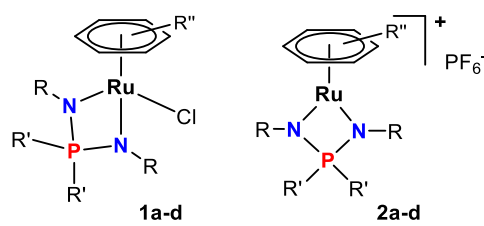

a: $\mathrm{Ar}=\mathrm{C}_{6} \mathrm{Me}_{6}, \mathrm{R}=p-\mathrm{Tol}, \mathrm{R}^{\prime}=\mathrm{Ph}$ b: $\mathrm{Ar}=\mathrm{C}_{6} \mathrm{Me}_{6}, \mathrm{R}=p$-Tol, $\mathrm{R}^{\prime}=\mathrm{Et}$ c: $\mathrm{Ar}=\mathrm{C}_{6} \mathrm{Me}_{6}, \mathrm{R}=\mathrm{Me}, \mathrm{R}^{\prime}=\mathrm{Ph}$ d: $\mathrm{Ar}=p-\mathrm{Cym}, \mathrm{R}=p-\mathrm{Tol}, \mathrm{R}^{\prime}=\mathrm{Ph}$

Chart 1. 


\section{Results and Discussion}

Synthesis and characterization of the complexes $1 \mathrm{~d}$ and $\mathbf{2 d}$.

The new $p$-cymene ruthenium NPN-complexes $(\mathbf{1} \mathbf{d}, \mathbf{2} \mathbf{d})$ were synthesized similarly to their hexamethylbenzene analogues $\mathbf{1 a}$ and $\mathbf{2 a},{ }^{[15]}$ i.e. by reacting $\left[(p \text {-cymene }) \mathrm{RuCl}_{2}\right]_{2}$ with iminophosphonamide $\mathbf{A}$ after deprotonation with 1 equiv. of NaHMDS to obtain 1d and further abstraction of the chloride ligand with $\mathrm{AgPF}_{6}$ to yield the corresponding 16ē cationic complex 2d (Scheme 1). The isolated products were fully characterized by NMR spectroscopy and elemental analysis, and their molecular structures were confirmed by single crystal $\mathrm{X}$-ray diffraction studies (Figures 1 and 2, Table S6 in ESI).

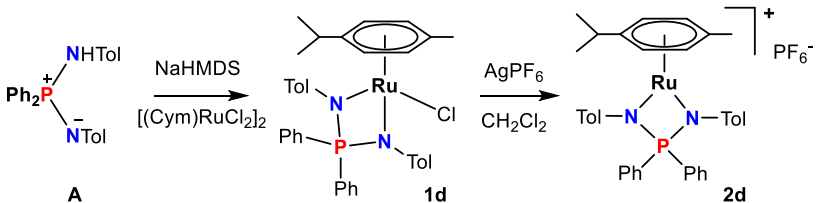

Scheme 1. Synthesis of the complexes $\mathbf{1 d}, \mathbf{2 d}$.
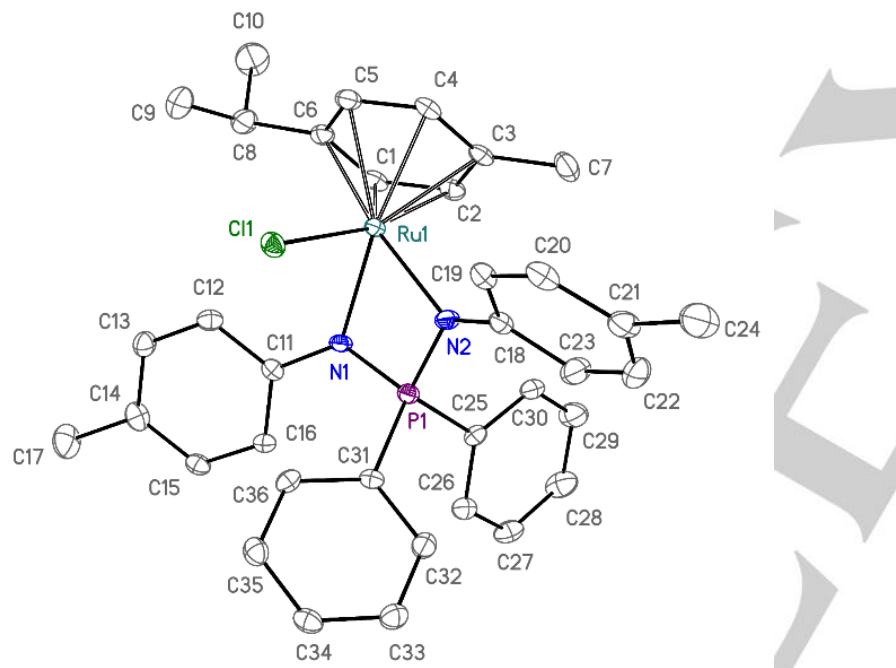

Figure 1. ORTEP diagram of 1d. Ellipsoids are shown at the $50 \%$ probability level; hydrogen atoms are omitted for clarity. Selected bond lengths $(\AA)$ and angles $\left({ }^{\circ}\right)$ : Ru…Arene(centroid) 1.667(1), Ru-Cl 2.415(1), Ru-N1 2.145(2), Ru-N2 2.126(3), N1-Ru-N2 68.24(9), Ru-N1-P-N2 178.43(16), $\quad$ (N1) $357.2(6), \Sigma(\mathrm{N} 2) 358.2(6)$

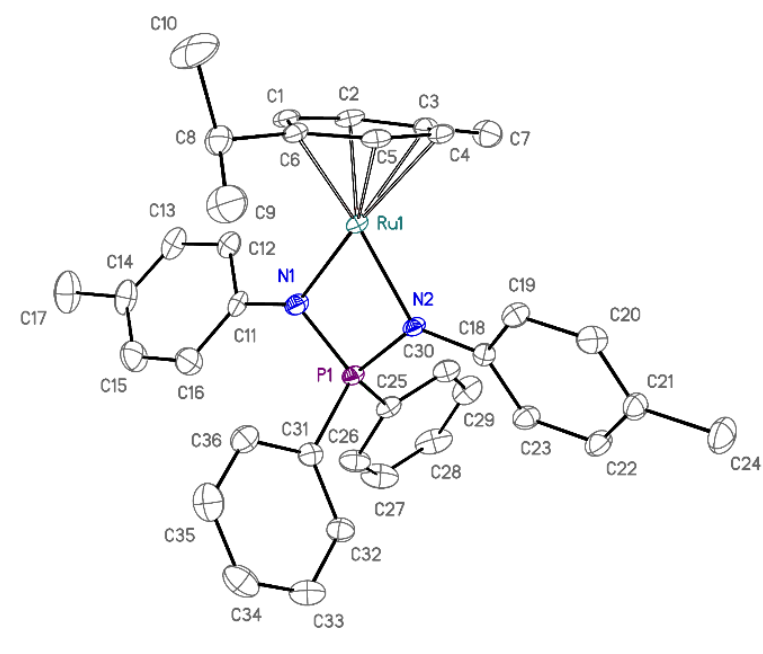

Figure 2. ORTEP diagram of the cation 2d. Ellipsoids are shown at the 50\% probability level; hydrogen atoms and the anion are omitted for clarity. Selected

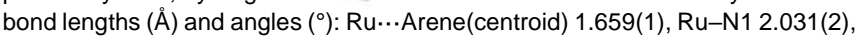
Ru-N2 2.017(3), N1-Ru-N2 72.42(10), Ru-N1-P-N2 174.27(15), $\Sigma(\mathrm{N} 1)$ $360.0(6), \Sigma(\mathrm{N} 2) 358.9(5)$

The 18ē complex 1d exhibits a three-legged piano stool geometry with a pseudo octahedral configuration of the ligands around the ruthenium atom. The structural parameters of $\mathbf{1 d}$ are similar to those of its $\mathrm{C}_{6} \mathrm{Me}_{6}$ analogues 1a-c, except for the $\mathrm{Ru}-\mathrm{N}$ and $\mathrm{Ru}-\mathrm{Cl}$ distances that are about $0.02 \AA$ shorter (the average $\mathrm{Ru}-\mathrm{N}$ and $\mathrm{Ru}-\mathrm{Cl}$ bond lengths in 1a-c are 2.148-2.156(4) $\AA$ and 2.437-2.445(4) $\AA$, respectively). ${ }^{[15]}$ The $p$-cymene ligand is a weaker donor and has lower steric requirements than $\mathrm{C}_{6} \mathrm{Me}_{6}$, hence the lack of electron density on the ruthenium atom in $\mathbf{1 d}$ is compensated by shortening the bonds with the NPN and $\mathrm{Cl}$ ligands. The pyramidalization of the nitrogen atoms, as indicated by $\Sigma(N)$, is small like for the complexes $\mathbf{1 a , b}$. This is a result of the ability of the $\mathrm{N}$-tolyl substituents in $\mathbf{1} \mathbf{a}, \mathbf{b}, \mathbf{d}$ to delocalize the unshared electron density of the nitrogen atoms, in sharp contrast with the severe pyramidalization of one of the nitrogen atoms in 1c $\left(\Sigma(\mathrm{N} 1)=344.4^{\circ}\right)$, for which such delocalization is impossible.

The 16ē cationic complex $\mathbf{2 d}$ exhibits a two-legged pianostool geometry with the chelating NPN-ligand positioned nearly perpendicular to the $p$-cymene ligand. Most of the structural parameters of $\mathbf{2 d}$ are similar to those of its $\mathrm{C}_{6} \mathrm{Me}_{6}$ counterparts $\mathbf{2 a , b}$, besides less significant distortion of the arene ligand. The p-cymene ligand in $\mathbf{2 d}$ is almost planar ( $\mathrm{Ru}-\mathrm{C}$ (arene) bonds in the 2.159-2.204(3) $\AA$ range) compared to the $\mathrm{C}_{6} \mathrm{Me}_{6}$ ring in $2 \mathrm{a}$ and $\mathbf{2 b}$, which is bent towards a boat conformation with two considerably longer $\mathrm{Ru}-\mathrm{C}$ (arene) bonds (trans to $\mathrm{Ru}-\mathrm{N} ; 2.228$ 2.275(2) $\AA$ ) vs. the other four $(2.143-2.201(2) \AA) .{ }^{[15]}$ This structural peculiarity may result from weaker back-bonding from the ruthenium atom to the arene ligand in $\mathbf{2 d}$.

The geometrical differences observed for the $\mathrm{C}_{6} \mathrm{Me}_{6}$ and $p$ cymene complexes were reproduced by the density functional theory (DFT) calculation performed for $\mathbf{1 a}, \mathbf{1 d}, \mathbf{2} \mathbf{a}$ and $\mathbf{2 d}$ in the gas phase with PBE functional and def2-TZVP basis set. The optimized structures differ from the experimentally determined 
ones by $<0.03 \AA$ for the distances and $<2^{\circ}$ for the bond angles (ESI, Tables S7 and S8). It is noteworthy that the DFT calculations also predict the arene orientation relative to the $\mathrm{Cl}, \mathrm{N}, \mathrm{N}$ atoms in 1a and $\mathbf{1 d}$ (the dihedral angle $\mathrm{Cl}-\mathrm{Ru}-\mathrm{Centroid}-\mathrm{C} 5$ differs by $<3^{\circ}$ ). Coordination of the arene ligand in the $16 \bar{e}$ complexes $\mathbf{2 a}$ and $\mathbf{2 d}$ has a well-pronounced $\eta^{2}-\eta^{2}$ character, with the Ru-C1 and RuC4 bonds being ca. $0.04 \AA$ (2d) or $0.09 \AA$ (2a) longer than the other four $\mathrm{Ru}-\mathrm{C}$ bonds, which also indicates a stronger distortion of the planar arene ring towards a boat conformation for $\mathbf{2 a}$ than for $\mathbf{2 d}$. This pattern can be explained by the symmetry of the ruthenium orbitals interacting with the arene ring (see below).

The $16 \bar{e}$ complexes $\mathbf{2 a}-\mathbf{c}$ exhibit a moderate intensity band in the UV-vis spectra centered at $540-550 \mathrm{~nm},{ }^{[15]}$ which was supposed to belong to a $d-d^{*}$ transition. The UV-Vis spectra of $\mathbf{2 d}$ exhibit a similar band, although surprisingly shifted to longer wavelengths $\left(\lambda_{\max }=590 \mathrm{~nm}\right)$. According to the calculated orbital pattern of $\mathbf{2 a}$ and $\mathbf{2} \mathbf{d}$, the highest occupied molecular orbitals (HOMO) (ESI, Fig. S10) of both cations are assigned to the antibonding combination of the ruthenium $d_{x y}$ orbital with the $A_{2}-$ symmetric group orbital of the NPN ligand (linear combination of the nitrogen atoms $p_{y}$ orbitals) and are located at very close energies (-7.4 eV in the gas phase and $-5.1 \mathrm{eV}$ in $\mathrm{CH}_{2} \mathrm{Cl}_{2}$ solution, Table 1). In both $\mathbf{2 a}$ and $\mathbf{2 d}$, the lowest unoccupied molecular orbital (LUMO) (ESI, Fig. S11) is a combination of the ruthenium unoccupied $d_{y z}$ orbital and occupied $B_{2} \pi$-orbital of the arene ligand. Lowering the energy of the corresponding bonding orbital (HOMO-14, see ESI, Fig. S12) is responsible for the elongation of two $\mathrm{C}-\mathrm{C}$ bonds $(\mathrm{C} 2-\mathrm{C} 3$ and $\mathrm{C} 5-\mathrm{C} 6)$ of the $\eta^{6}$-arene ligand. The greater electron-donating ability of $\mathrm{C}_{6} \mathrm{Me}_{6}$ leads to a higher energy LUMO by $0.4 \mathrm{eV}$ in 2a (Table 1). Hence the bands observed at $540 \mathrm{~nm}(\mathbf{2 a})$ and $590 \mathrm{~nm}(\mathbf{2 d})$ in the UV-vis spectra appear consistent with a ligand-to-metal charge-transfer transition, as in the $16 \bar{e}$ arene ruthenium dithiolate complexes. ${ }^{[17]}$ The HOMOLUMO gap for 2a and $\mathbf{2 d}$ are calculated in $\mathrm{CH}_{2} \mathrm{Cl}_{2}$ as 2.05 and $1.65 \mathrm{eV}$ (Table 1), respectively, thus reflecting a significant red shift for the absorption of $\mathbf{2} \mathbf{d}$ compared to $\mathbf{2} \mathbf{a}$.

Table 1. The HOMO, LUMO energies and the HOMO-LUMO gap for $\mathbf{2 a}$ and 2d calculated in the gas phase and $\mathrm{CH}_{2} \mathrm{Cl}_{2}$ solution in comparison to the energy of the experimentally observed band (all in eV).

\begin{tabular}{lllll}
\hline & \multicolumn{2}{c}{ 2a } & \multicolumn{2}{c}{ 2d } \\
\cline { 2 - 5 } & Gas phase & $\mathrm{CH}_{2} \mathrm{Cl}_{2}$ & Gas phase & $\mathrm{CH}_{2} \mathrm{Cl}_{2}$ \\
\hline HOMO & -7.45 & -5.06 & -7.37 & -5.05 \\
LUMO & -5.50 & -3.01 & -5.92 & -3.40 \\
Gap & 1.95 & 2.05 & 1.45 & 1.65 \\
Expt & & 2.32 & & 2.10 \\
\hline
\end{tabular}

It should be noted that the LUMO in complexes $\mathbf{2}$ is the orbital available to accept the electron pair donated by the external ligand $(\mathrm{L}$ or $\mathrm{Cl})$ upon formation of the $18 \bar{e}$ adduct. Hence, the lower energy of the LUMO in $\mathbf{2} \mathbf{d}$ is responsible for the stronger bonding of chlorine atom in the $p$-cymene complex vs those containing $\mathrm{C}_{6} \mathrm{Me}_{6}$, as reflected by the computed and measured $\mathrm{Ru}-\mathrm{Cl}$ bond lengths (Tables S7 and S8).

\section{Coordination lability of complexes $1 \mathrm{a}-\mathrm{d}$}

Despite the low symmetry $\left(C_{1}\right)$ of $\mathbf{1 d}$ in the solid state, only two doublets at $\delta 5.05$ and $4.87\left(\mathrm{C}_{6} \mathrm{D}_{6}\right)$ were observed for the coordinated arene in the ${ }^{1} \mathrm{H}$ NMR spectrum, as well as two singlets at $\delta 79.4,80.7$ in the ${ }^{13} \mathrm{C}$ NMR spectrum, because of facile rotation of the $p$-cymene ring around the $\mathrm{Ru}$-Arene axis yielding an effective $C_{s}$ symmetry in solution. The NMR spectral feature of $\mathbf{2} \mathbf{d}$ are equally in accord with $C_{\mathbf{s}}$-symmetry. On the other hand, the ${ }^{1} \mathrm{H}$ and ${ }^{13} \mathrm{C}$ NMR spectra for the P-phenyl substituents of $1 \mathbf{d}$ exhibit the expected two sets of signals in $\mathrm{C}_{6} \mathrm{D}_{6}$ but only one in $\mathrm{CDCl}_{3}$, suggesting an even higher (effective $C_{2 \mathrm{v}}$ ) point group symmetry in the latter solvent. This can be rationalized, in addition to the rapid $p$-cymene ring rotation around the $\mathrm{Ru}-\mathrm{Arene}$ axis, by the reversible dissociation of the $\mathrm{Ru}-\mathrm{Cl}$ bond that yields an equilibrium mixture of the effectively $C_{2 v}$-symmetric intermediate $[2]^{+} \mathrm{Cl}^{-}$and undissociated $\mathbf{1}$, as has been previously proposed for 1c. ${ }^{[15]}$ However, whether this process may occur in apolar solvents and what is the dissociation enthalpy as a function of solvent, NPN substituents and type of arene ligand is still open to question. The additional studies detailed below have brought light on this point.

UV-vis spectroscopic studies of $\mathbf{1 b}$ and $\mathbf{1 c}$ in polar solvents. As we have previously reported, ${ }^{[15]}$ complex $1 \mathrm{c}$ bearing the most electron-releasing $\mathrm{N}-\mathrm{Me}$ groups partially dissociates in the relatively polar solutions to give the corresponding cationic species $\left[2 \mathrm{c}^{+} \mathrm{Cl}^{-}\right.$(Scheme 2), as revealed by the strong downfield shift of its ${ }^{31} \mathrm{P}$ NMR resonance in dichloromethane compared to $\mathrm{C}_{6} \mathrm{D}_{6}$. The detailed study by means of UV-vis spectroscopy revealed the distinct absorption bands in toluene for 1c (at 430 $\mathrm{nm}$ ) and 2c (at $550 \mathrm{~nm}$; ESI, Fig. S1A,B). The spectrum of 1c in $\mathrm{CH}_{2} \mathrm{Cl}_{2}$ shows a very broad absorption band located in-between these bands (at $520 \mathrm{~nm}$; Fig. 3), thus suggesting the coexistence of the dissociated and undissociated forms. The spectra are temperature dependent in the range 190-290 K, showing reversible changes with an isosbestic point at $\lambda=480 \mathrm{~nm}$ (Fig. 3). The standard enthalpy and entropy for the dissociation process (Scheme 2) were calculated from the Van't Hoff equation using the T-dependent molar extinction coefficient of $2 c$ at $\lambda=600 \mathrm{~nm}$. The dissociation process is exothermic $\left(\Delta H_{\mathrm{d}}=-5.0 \pm 0.2 \mathrm{kcal} / \mathrm{mol}\right)$, with the cationic form dominating at low temperatures. The unexpectedly large negative entropy change $\left(\Delta S_{d}=-27.0 \pm 0.7\right.$ $\mathrm{cal} /(\mathrm{mol} \cdot \mathrm{K}))$ for the dissociation process is attributed to the need to re-organize the solvent dipoles around the charged species ${ }^{[18]}$ formed upon dissociation of $\mathbf{1 c}$

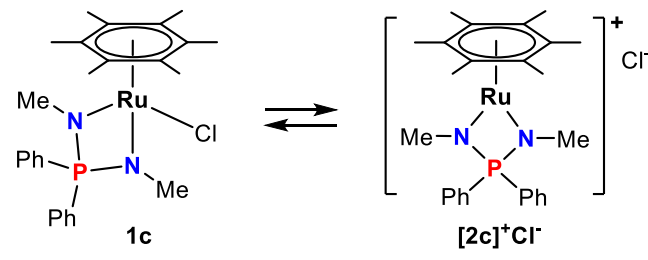

Scheme 2. Chloride dissociation from complex 1c. 


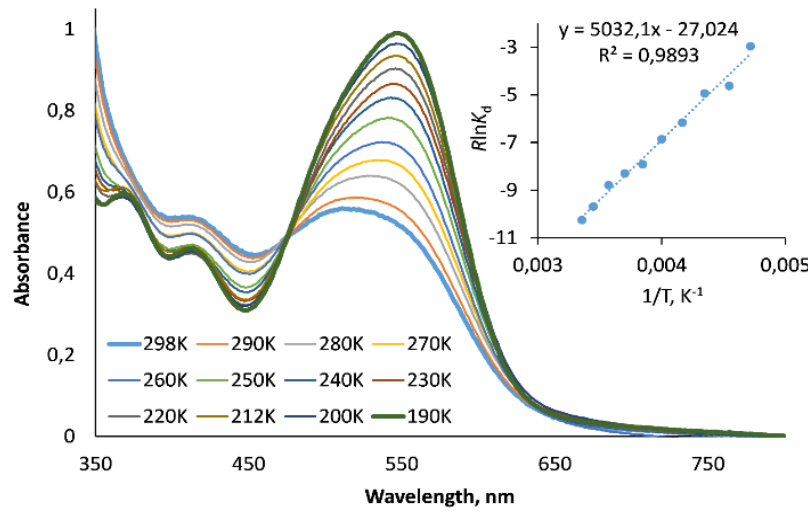

Figure 3. UV-vis spectra of 1c in $\mathrm{CH}_{2} \mathrm{Cl}_{2}$ at $190-298 \mathrm{~K}$. The insert shows the Van't Hoff plot of $R \ln K_{\mathrm{d}}$ vs $1 / \mathrm{T}$.

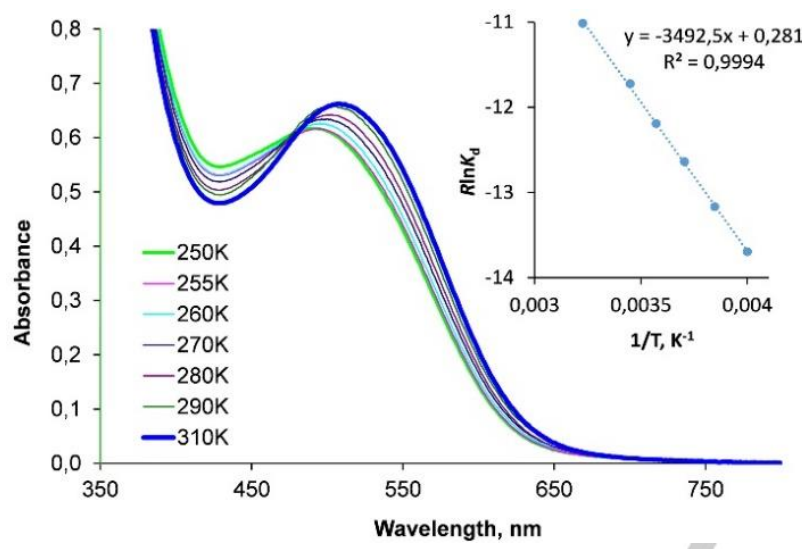

Figure 4. UV-vis spectra of $\mathbf{1 b}$ in $\mathrm{MeNO}_{2}$ at $250-310 \mathrm{~K}$. The insert shows the Van't Hoff plot of $R \ln K d$ vs $1 / T$.

Complex 1b, bearing an NPN-ligand with the less electronreleasing $p$-tolyl substituents on the nitrogen atoms, does not show any evidence of chloride dissociation in $\mathrm{CH}_{2} \mathrm{Cl}_{2}$. The UV-vis spectrum is T-independent and only the undissociated $18 \overline{\mathrm{e}}$ complexes is present in solution as shown by the band centered at $450 \mathrm{~nm}$ (ESI, Fig. S2). However, the compound predominantly exists as cationic complex [2b] ${ }^{+} \mathrm{Cl}^{-}$in solution of the highly polar $\mathrm{MeNO}_{2}$ solvent, exhibiting a band with $\lambda_{\max }=515 \mathrm{~nm}$ (Fig. 4). Analysis of the temperature dependence of this band in the range $250-310 \mathrm{~K}$ gave $\Delta H_{\mathrm{d}}=3.5 \pm 0.2 \mathrm{kcal} / \mathrm{mol}$ and $\Delta S_{\mathrm{d}}=+0.3 \pm 0.6$ $\mathrm{cal} /(\mathrm{mol} \cdot \mathrm{K})$. Compared to the dissociation of $1 \mathrm{c}$ in $\mathrm{CH}_{2} \mathrm{Cl}_{2}$, the more positive dissociation entropy of $\mathbf{1} \mathbf{b}$ in $\mathrm{MeNO}_{2}$ is attributed to a more efficient solvation of the charged species by $\mathrm{MeNO}_{2}$. On the other hand, both 1a and $\mathbf{1 d}$, which contain the least donating NPN-ligand, do not noticeably dissociate even in $\mathrm{MeNO}_{2}$ as suggested by the absorption band at $450 \mathrm{~nm}$ in their visible spectra, even though the insufficient solubility of both compounds did not allow verification of the temperature independence of these spectra.

NMR study of 1a-d in apolar solvents. The chloride complexes 1a-c show two inequivalent $\mathrm{P}$-Ph groups in their RT-NMR spectra in apolar solvents (benzene, toluene), meaning they exist as $C_{s^{-}}$ symmetric $18 \overline{\mathrm{e}}$ complexes on the NMR timescale. ${ }^{[15]}$ We now report that heating the solution of $1 \mathrm{c}$ in $\mathrm{C}_{6} \mathrm{D}_{6}$ to $338 \mathrm{~K}$ gives one set of signals for these groups, which is indicative of exchange. The coalescence of the two ortho-protons signals at $\delta 7.70$ and 7.98 is observed at $323 \pm 5 \mathrm{~K}\left(T_{\mathrm{c}}\right)$ (ESI, Fig. S3). From this temperature and from the chemical shift difference, the rate constant $\left(k_{\mathrm{ex}}=380 \mathrm{~s}^{-1}\right)$ and activation free energy $\left(\Delta G_{\mathrm{ex}}{ }^{\neq}=\right.$ $15.2 \pm 0.3 \mathrm{kcal} / \mathrm{mol}$ ) for the degenerative exchange process can be calculated. ${ }^{[19]}$ For complex 1b with a less donor NPN-ligand, coalescence for the P-Et methyl resonances at $\delta 0.40$ and 1.39 could not be reached below the boiling point of toluene- $d_{8}(\mathrm{ESI}$, Fig. S4). However, we observed slow exchange of the ethyl groups for this compound in $\mathrm{C}_{6} \mathrm{D}_{6}$ and in toluene- $d_{8}$ by the $2 \mathrm{D}$ EXSY ${ }^{1} \mathrm{H}$ NMR method (Fig. 5), ${ }^{[20]}$ yielding the rate constants of $1.8 \mathrm{~s}^{-1}$ and $1.4 \mathrm{~s}^{-1}$ at $293 \mathrm{~K}$, respectively (Table 2, lines 3,7). The activation parameters for the exchange process were obtained from the temperature dependence of the exchange rate constants $\left(k_{\mathrm{ex}}\right)$ in toluene- $d_{8}$ in the range $230-315 \mathrm{~K}: \Delta H_{\mathrm{ex}}{ }^{\neq}=8.4 \pm 0.2$ $\mathrm{kcal} / \mathrm{mol}$ and $\Delta S_{\mathrm{ex}}{ }^{\ddagger}=-29.2 \pm 0.7 \mathrm{cal} /(\mathrm{mol} \cdot \mathrm{K})$ (ESI, Fig. S5, Table $\mathrm{S} 1)$.

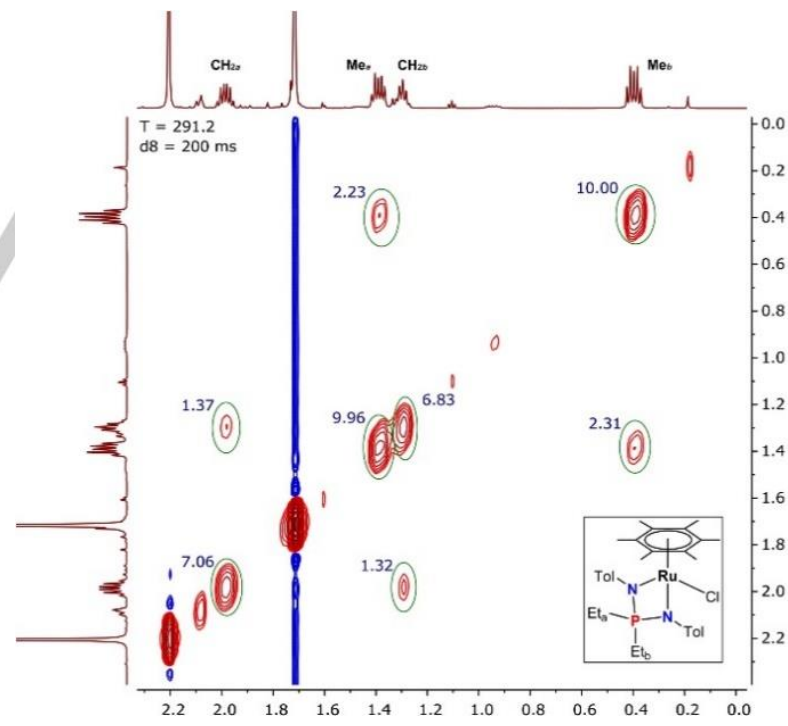

Figure 5. 2D EXSY ${ }^{1} \mathrm{H}$ NMR of $1 \mathrm{~b}$ in toluene- $d_{8}$ at $291 \mathrm{~K}$ and the mixing time of $200 \mathrm{~ms}$. 
Table 2. Exchange rate constant $k_{\mathrm{ex}}\left(\mathrm{s}^{-1}\right)$ and activation free energy $\Delta G_{\mathrm{ex}}{ }^{\ddagger}(\mathrm{kcal} / \mathrm{mol})$ for the $\mathrm{P}$-bound substituent exchange in $\mathbf{1 a}, \mathbf{1} \mathbf{b}$ and $1 \mathrm{~d}$ from the $2 \mathrm{D}$ EXSY ${ }^{1} \mathrm{H}$ NMR investigations.

\begin{tabular}{|c|c|c|c|c|c|c|c|c|}
\hline & Complex & Solvent & Additives & $\mathrm{C}(\mathrm{Ru}), \mathrm{mM}$ & $\mathrm{C}(\mathrm{add}), \mathrm{mM}$ & $T, \mathrm{~K}$ & $k_{\mathrm{ex}}, \mathrm{s}^{-1}$ & $\Delta G_{\mathrm{ex}^{\ddagger}}, \mathrm{kcal} / \mathrm{mol}$ \\
\hline 1 & $1 a$ & $\mathrm{C}_{6} \mathrm{D}_{6}$ & - & 10 & & 293 & $<0.1$ & $>18.5$ \\
\hline 2 & $1 \mathrm{a}$ & $\mathrm{C}_{6} \mathrm{D}_{6}$ & $\mathrm{H}_{2} \mathrm{O}$ & 10 & 10 & 294 & 0.79 & 17.4 \\
\hline 3 & $1 b$ & $\mathrm{C}_{6} \mathrm{D}_{6}$ & - & 20 & & 293 & 1.8 & 16.8 \\
\hline 4 & $1 b$ & $\mathrm{C}_{6} \mathrm{D}_{6}$ & $\mathrm{H}_{2} \mathrm{O}$ & 20 & 5 & 295 & $>15$ & $<15.7$ \\
\hline 5 & $1 b$ & Toluene & - & 40 & & 295 & 1.6 & 17.0 \\
\hline 6 & $1 b$ & Toluene & - & 8 & & 295 & 1.6 & 17.0 \\
\hline 7 & $1 b$ & Toluene & - & 46 & & 293 & 1.4 & 17.0 \\
\hline 8 & $1 d$ & $\mathrm{C}_{6} \mathrm{D}_{6}$ & & 10 & & 293 & $<0.1$ & $>18.5$ \\
\hline 9 & $1 d$ & $\mathrm{C}_{6} \mathrm{D}_{6}$ & $\mathrm{H}_{2} \mathrm{O}$ & 10 & 0.7 & 293 & 0.72 & 17.3 \\
\hline 10 & $1 d$ & $\mathrm{C}_{6} \mathrm{D}_{6}$ & $\mathrm{H}_{2} \mathrm{O}$ & 10 & 2.4 & 293 & 2.6 & 16.6 \\
\hline 11 & 1d & $\mathrm{C}_{6} \mathrm{D}_{6}$ & $\mathrm{Et}_{4} \mathrm{~N}^{+} \mathrm{Cl}^{-}$ & 10 & 0.7 & 292 & $>11$ & $<15.7$ \\
\hline
\end{tabular}

A large negative value of the activation entropy evidences a highly ordered transition state in the exchange process. The exchange between $\mathrm{R}_{a}{ }_{a}$ and $\mathrm{R}_{b}$ b substituents occurs via a configuration inversion at the $\mathrm{Ru}$ atom, which can most easily be envisaged by moving the chloride ligand from one coordination side to the opposite one by ligand exchange processes. Generally such ligand exchange may proceed either via a dissociative mechanism with a cationic 16ē intermediate (pathway $\mathbf{A}$ in Fig. $6 \mathrm{~A})$ or via a $\mathrm{S}_{\mathrm{N} 2}$-like associative mechanism through a $20 \mathrm{e}$ transition state (pathway B in Fig. 6B). In the latter case, however, configuration inversion with exchange of the phosphorus $\mathrm{R}_{\mathrm{a}}$ and $R^{\prime}{ }_{b}$ substituents could take place only when the entering ligand is $\mathrm{Cl}^{-}$. Given that the NMR and UV studies outlined above were carried out in non-coordinating solvents and coordinating ligands $\mathrm{L}$ are not present, the exchange in $\mathbf{1 6}$ most likely takes place via the dissociated complex $[\mathbf{2 b}]^{+} \mathrm{Cl}^{-}$, which requires an entropically unfavorable solvation of the chloride-ion by apolar molecules (Fig. $6 \mathrm{~A})$, similarly to the dissociation of $1 \mathrm{c}$ in $\mathrm{CH}_{2} \mathrm{Cl}_{2}$ described above. We have further confirmed that the exchange rates are independent on the concentration of $\mathbf{1 b}\left(1.6 \mathrm{~s}^{-1}\right.$ in both $40 \mathrm{mM}$ and $8 \mathrm{mM}$ toluene- $d_{8}$ solutions at $295 \mathrm{~K}$, Table 2 , lines 5,6$)$. The P substituent exchange for complexes 1a and 1d, which bear the least electron-donating NPN-ligand, is not observed by 2D EXSY ${ }^{1} \mathrm{H}$ NMR even at $t_{\mathrm{m}}=1 \mathrm{~s}$, hence the rates are slower than $0.1 \mathrm{~s}^{-1}$ and the activation free energies $\left(\Delta G_{e x}{ }^{\ddagger}\right)$ are greater than 18.5 $\mathrm{kcal} / \mathrm{mol}$.
A

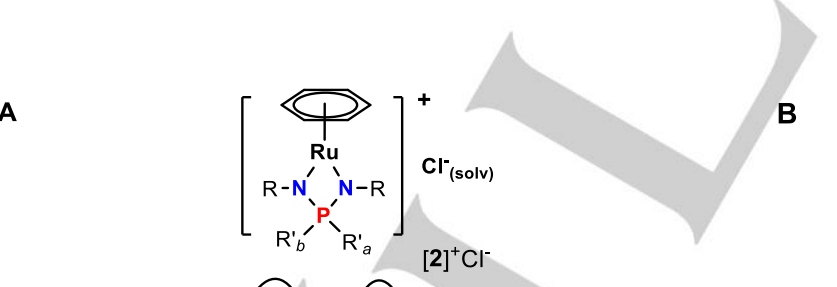

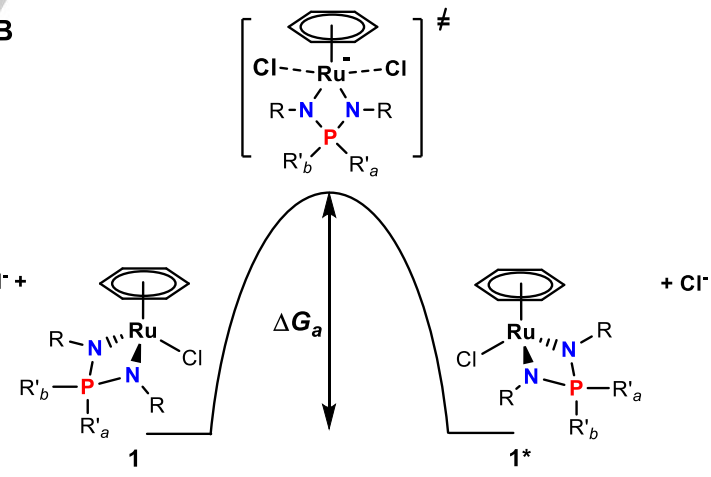

Figure 6. Dissociative (A) and associative (B) mechanisms for the exchange of the R'a and R'b groups in 1. 
In principle, addition of $\mathrm{Cl}^{-}$should either slow down or accelerate the exchange depending on whether the mechanism is $\mathbf{A}$ or $\mathbf{B}$, respectively. Addition of 0.07 equiv. of $\mathrm{Et}_{4} \mathrm{~N}^{+} \mathrm{Cl}^{-}$to $\mathbf{1 d}$ strongly enhances the exchange process $\left(k_{\mathrm{ex}}>11 \mathrm{~s}^{-1}\right)$. This result strongly suggests that the exchange occurs by the associative mechanism B under these conditions (Table 2, line 11, and ESI, Fig. S6). Therefore, it seems that both mechanisms $\mathbf{A}$ and $\mathbf{B}$ are possible, the former in the absence of added $\mathrm{Cl}^{-}$and the latter in its presence.

Assistance by an external ligand $\mathrm{L}$ may also result in $\mathrm{Cl}^{-}$release. While the subsequent attack of the same Ru- $\mathrm{L}$ intermediate by $\mathrm{Cl}^{-}$ would not result in any $\mathrm{P}$ substituent exchange, attack of another $\mathrm{Ru}-\mathrm{Cl}$ complex achieves a degenerative self-exchange with configuration inversion and $P$ substituent exchange (Fig. 7). Thus, the P-phenyl group exchange for these compounds becomes observable after adding water to the $\mathrm{C}_{6} \mathrm{D}_{6}$ solutions (cf. lines 1,2 for $\mathbf{1 a}$ and lines 8,9 for $\mathbf{1 d}$ ) and the rate constants are found to increase with the increase of the water content (Table 2, lines 9,10; ESI, Fig. S7). For the 1d sample with $\left[\mathrm{H}_{2} \mathrm{O}\right]=0.7 \mathrm{mM}(0.07$ equiv.), the activation parameters could be derived from the temperature dependence (291-335 K) of $k_{\text {ex }}$ (ESI, Fig. S8, Table S2). The calculated activation enthalpy ${ }^{[1]} \Delta H_{\mathrm{ex}}{ }^{\neq}=11.8 \pm 0.2$ $\mathrm{kcal} / \mathrm{mol}$ of the associative exchange can be used as a lower limit for the $\Delta H_{\text {ex }}{ }^{*}$ in dissociative exchange of $\mathbf{1 d}$ in the absence of external ligands. It is pertinent to underline that water may have a double role in the promotion of the associative chloride exchange: as a ligand to replace $\mathrm{Cl}^{-}$in the coordination sphere of the $\mathrm{Ru}$ atom, and as a proton donor to stabilize the dissociated $\mathrm{Cl}^{-}$by $\mathrm{H}-$ bonding. Interestingly, the effect of water for $\mathbf{1 a}$ is much smaller; a rate constant of $0.79 \mathrm{~s}^{-1}$ is achieved only in the presence of an equimolar amount of $\mathrm{H}_{2} \mathrm{O}$ in $\mathrm{C}_{6} \mathrm{D}_{6}$. Perhaps the sterically bulky $\mathrm{C}_{6} \mathrm{Me}_{6}$ ligand hampers the $\mathrm{Cl}^{-}$or external ligand coordination thus increasing the activation free energy.

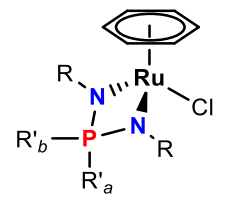

1

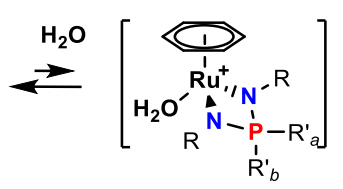

$\mathrm{Cl}^{-}$

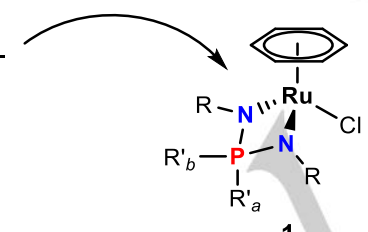

1

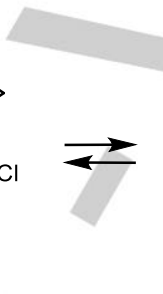

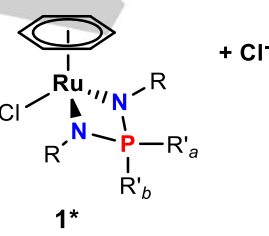

$1^{*}$

Figure 7. Associative exchange promoted by water-induced chloride dissociation.

We would like to underline that the activation enthalpy $\Delta H_{\mathrm{ex}}{ }^{\neq}$ for the exchange process in dissociative mechanism $\mathbf{A}$ should be very close to the $\mathrm{Ru}-\mathrm{Cl}$ bond dissociation enthalpy, $\Delta H_{\mathrm{d}}$. The latter depends predominantly on the $\mathrm{Ru}-\mathrm{Cl}$ bond strength and on the solvent polarity. Hence, the $\Delta H_{\mathrm{d}}$ value for complex 1c may be estimated from its $\Delta G^{\neq}$at $323 \mathrm{~K}$ as $\Delta H_{\mathrm{d}} \sim \Delta H_{\mathrm{ex}}{ }^{\neq}=\Delta G_{\mathrm{ex}}{ }^{\neq}+\mathrm{T} \Delta S_{\mathrm{ex}}{ }^{\neq}$, where $\Delta S_{\mathrm{ex}}{ }^{\ddagger}$ can be assumed to be close to that for $\mathbf{1 b}(-29.2$ $\mathrm{cal} /(\mathrm{mol} \cdot \mathrm{K}))$. This gives an estimate for the $\Delta H_{\mathrm{d}}$ of $1 \mathrm{c}$ as ca. 5.7 $\mathrm{kcal} / \mathrm{mol}$. Analogously, the $\Delta H_{\mathrm{d}}$ of $1 \mathrm{a}$ and $1 \mathrm{~d}$ can be estimated as $>10 \mathrm{kcal} / \mathrm{mol}$. Thus, we have proved that the $\mathrm{Ru}-\mathrm{Cl}$ bond in $18 \overline{\mathrm{e}}$ arene ruthenium iminophosphonamide complexes can dissociate even in apolar solvents. The $\Delta H_{d}$ for $\mathbf{1 a - d}$ expectedly lowers with an increase of the ligand donating ability: over $10 \mathrm{kcal} / \mathrm{mol}(\mathbf{1 a}$, 1d) $>8.4 \mathrm{kcal} / \mathrm{mol}(\mathbf{1 b})>5.7 \mathrm{kcal} / \mathrm{mol}(\mathbf{1 c})$.

\section{Coordination of ligands to the $16 \mathrm{e}$ cationic complexes 2}

We have previously mentioned that the $16 \bar{e}$ cationic complex 2a interacts with $\mathrm{MeCN}$ and $\mathrm{CO}$, but failed to isolate these unstable adducts. ${ }^{[15]}$ We have now studied the activity of the $16 \overline{\mathrm{e}}$ complexes 2 towards coordination of external ligands $L$ (MeCN, pyridine, CO) in detail by means of UV-Vis and NMR spectroscopies (Scheme 3) to determine the thermodynamics of the process and with regard to the conditions allowing isolation. Since $1 \mathrm{a}$ is, among the $18 \overline{\mathrm{e}}$ chloride complexes $\mathbf{1}$, the least prone to chloride dissociation, the corresponding $16 \bar{e}$ complex $2 a$ is expected to display the highest affinity toward saturation by coordination of $\mathrm{L}$ ligands. Hence, the coordination of relatively weak donors MeCN and Py was studied for $\mathbf{2 a}$ only.
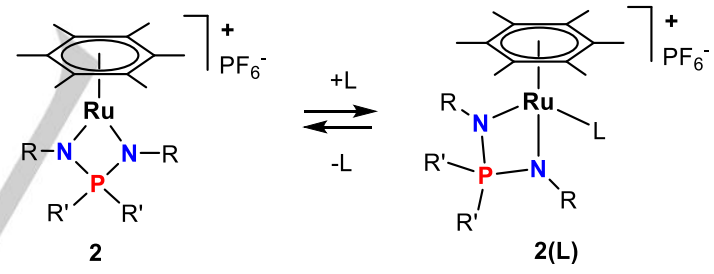

Scheme 3.

The titration of $\mathbf{2 a}$ with $\mathrm{MeCN}$ in $\mathrm{CH}_{2} \mathrm{Cl}_{2}$ at $296 \mathrm{~K}$ with UV-Vis monitoring shows that the intensity of the $535 \mathrm{~nm}$ band does not significantly change until $>100$ equiv. of $\mathrm{MeCN}$ are added (ESI, Fig. S9A), while a similar amount of pyridine significantly extinguishes this band to give rise a new band of the pyridine adduct at $445 \mathrm{~nm}$ (ESI, Fig S9B). The estimated equilibrium constants $K_{\mathrm{c}}$ are $<2 \mathrm{M}^{-1}$ for $2 \mathrm{a} \cdot \mathrm{MeCN}$ and $32 \pm 7 \mathrm{M}^{-1}$ (from UV-vis), $37 \pm 1 \mathrm{M}^{-1}$ (from NMR, ESI, Fig. S9C) for $\mathbf{2 a} \cdot \mathrm{Py}$, (ESI, Tables S3S5). The UV-vis measurements carried out for the 1:2 mixture of 2a:Py in the temperature range 200-296 K show that 2a dominates at room temperature, while the equilibrium shifts towards formation of the $18 \bar{e}$ adduct $\mathbf{2 a} \cdot \mathbf{P y}$ at lower temperatures. The conversion becomes essentially complete below $220 \mathrm{~K}$ (Fig. 8). The analysis of the Van't Hoff's plot yields $\Delta H_{\mathrm{c}}=-12.4 \pm 0.5$ $\mathrm{kcal} / \mathrm{mol}$ and $\Delta S_{\mathrm{c}}=-36 \pm 2 \mathrm{cal} /(\mathrm{mol} \cdot \mathrm{K})$. Thus, pyridine coordination is moderately exothermic, but a large excess of pyridine is 
required to observe coordination at room temperature because of high association entropy. This is in sharp contrast with the previously reported irreversible coordination of pyridine to the $16 \overline{\mathrm{e}}$ arene ruthenium amidinate complex $\left[\left(\mathrm{C}_{6} \mathrm{H}_{6}\right) \mathrm{Ru}\left({ }^{t} \mathrm{BuN}-\mathrm{C}(\mathrm{Ph})-\right.\right.$ $\left.\left.\mathrm{N}^{t} \mathrm{Bu}\right\}\right]\left(\mathrm{BAr}_{4}\right) \cdot{ }^{10}$

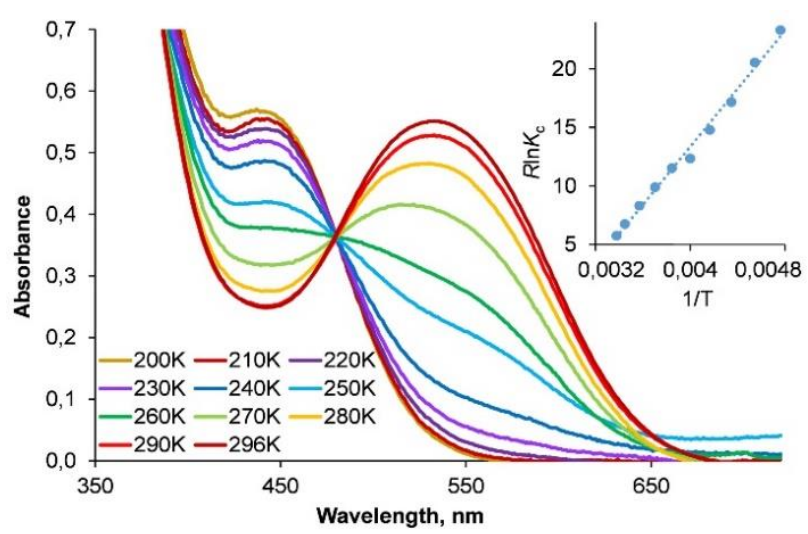

Figure 8. UV-vis spectra of reversible coordination of pyridine to $2 \mathbf{a}$ in $\mathrm{CH}_{2} \mathrm{Cl}_{2}$ at 200-296K. The insert shows the Van't Hoff dependence of $R \ln K_{\mathrm{c}} v s 1 / \mathrm{T}$.

In comparison with acetonitrile and pyridine, carbon monoxide is a stronger $\pi$-acceptor and reacts readily with $\mathbf{2 a}$ to give the $\mathrm{CO}$ adduct $3 \mathbf{a}$. However, the reaction is reversible and facile $\mathrm{CO}$ decoordination occurs upon solvent evaporation to give back $\mathbf{2 a}$. Nevertheless, 3a could be isolated by precipitation from its $\mathrm{CH}_{2} \mathrm{Cl}_{2}$ solution upon addition of excess diethyl ether. Analogously, the reaction of $\mathbf{2} \mathbf{d}$ with CO resulted in formation of $\mathbf{3 d}$, which is stable only under a $\mathrm{CO}$ atmosphere. This product was isolated, like $\mathbf{3 a}$, by using CO-saturated $\mathrm{CH}_{2} \mathrm{Cl}_{2}$ solution and diethyl ether. Although 3a and $\mathbf{3 d}$ slowly evolve $\mathrm{CO}$ in the solid state under vacuum, satisfactory elemental analyses were obtained for both. It should be noted that $\mathbf{3 a}$ is stable in a CO-saturated solution, whereas $\mathbf{3 d}$ degrades within days to unknown arene-free carbonyl complexes, perhaps similar to the previously observed ones resulting from the decomposition of $[(p-$ Cymene $\left.\mathrm{Ru}(\mathrm{CO})(\mathrm{SXyl})_{2}\right]^{\left[{ }^{[22]}\right.}$ The molecular structures of $3 \mathbf{a}, \mathbf{d}$ were determined by single crystal $X$-ray diffraction (ESI, Table S6). Selected structural parameters and views of the molecules are shown in Figures 9 and 10.

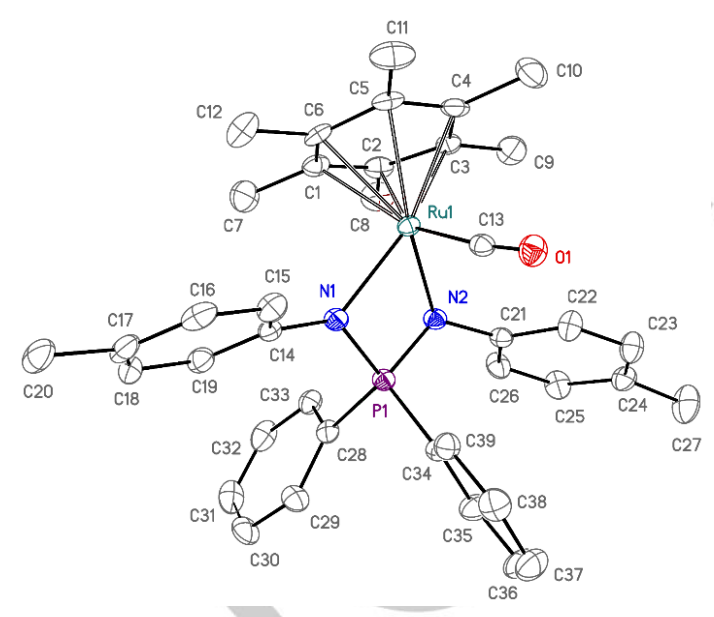

Figure 9. ORTEP diagram of the cation 3a. Ellipsoids are shown at the $50 \%$ probability level. The hydrogen atoms and the anion are omitted for clarity.

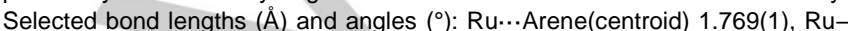
$\mathrm{C}(\mathrm{O})$ 1.871(3), Ru-N1 2.112(2), Ru-N2 2.116(2), C-O 1.145(3), N1-Ru-N2 69.20(9), Ru-N1-P-N2 164.60(15), $\Sigma(\mathrm{N} 1)$ 348.3(5), $\Sigma(\mathrm{N} 2)$ 359.3(5).

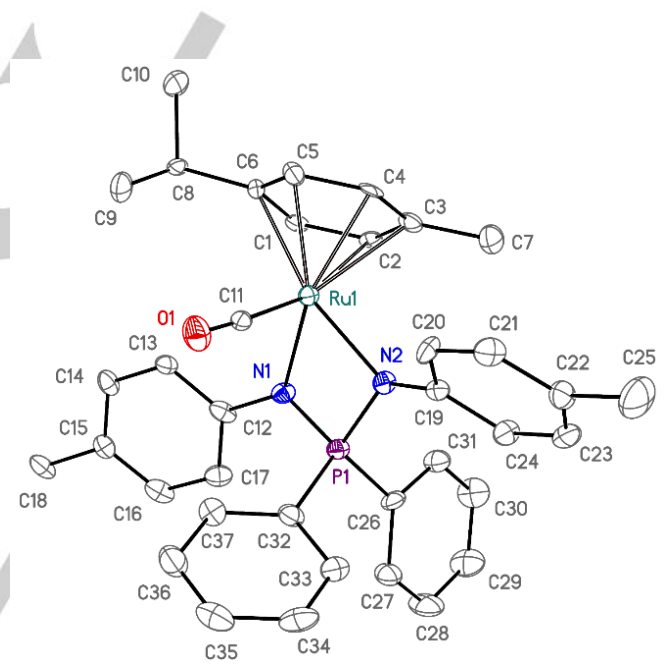

Figure 10. ORTEP diagram of the cation 3d. Ellipsoids are shown at the 50\% probability level. The hydrogen atoms and the anion are omitted for clarity. Selected averaged bond lengths $(\AA)$ and angles $\left({ }^{\circ}\right)$ : Ru...Arene(centroid) 1.768(3), Ru-C(O) 1.879(9), Ru-N1 2.095(7), Ru-N2 2.120(6), C-O 1.145(10), N1-Ru-N2 68.9(3), Ru-N1-P-N2 165.8(4), $\Sigma(\mathrm{N} 1)$ 353.7(13), $\Sigma(\mathrm{N} 2)$ 355.3(14).

Complexes $\mathbf{3 a}$ and $\mathbf{3 d}$ are the first crystallographically characterized arene ruthenium carbonyl derivatives with any $k^{2}$ $\mathrm{N}, \mathrm{N}$-anionic chelate ligand. The asymmetric unit of $\mathbf{3 d}$ contains two independent molecules, which exhibit identical metric parameters within experimental error. Both complexes exhibit a three-legged piano stool geometry with a pseudo octahedral configuration of the ligands around the ruthenium atom. The coordinated arene adopts a nearly staggered (3a) or eclipsed (3d) conformation relative to the $\mathrm{Ru}-\mathrm{CO}$ axis, with $\mathrm{C} 4-$ Arene(centroid)-Ru-CO angles of $25.7^{\circ}$ and $5.9-6.4^{\circ}$, respectively. The presence of the $\mathrm{CO}$ ligand significantly increase the $\mathrm{Ru}$-Arene(centroid) distance by $\sim 0.1 \AA$ in both $3 \mathbf{a}$ and $\mathbf{3 d}$ relative to $\mathbf{2 a}(1.662(2) \AA)$ and $\mathbf{2 d}$. The $\mathrm{Ru}-\mathrm{C}($ arene) 
distances vary in the range 2.208-2.333(3) $\AA$ with the longest bonds being trans to the $\mathrm{CO}$ ligand. The $\mathrm{C}-\mathrm{C}$ bonds length (1.389(12)-1.452(4) $\AA$ ) in the coordinated arene slightly alternate with the shortest $\mathrm{C}-\mathrm{C}$ bond (1.389-1.403 $\AA$ ) located trans to the $\mathrm{CO}$ ligand. A similar Ru-Arene(centroid) (1.810 ̊), Ru-C(O) (1.846(4) $\AA$ ) and carbonyl C-O (1.133(7) $\AA$ ) distances, as well as elongations for the two $\mathrm{Ru}-\mathrm{C}$ (arene) bonds trans to $\mathrm{CO}$ (2.389$2.396 \AA$ ) were previously reported for the arene ruthenium dithiolate carbonyl complex $\left[\left(\eta^{6}-\mathrm{C}_{6} \mathrm{Me}_{6}\right) \mathrm{Ru}(\mathrm{CO})\left(\mathrm{S}_{2} \mathrm{C}_{6} \mathrm{H}_{4}\right)\right]$ (4)..$^{[17]}$ The Ru-N bonds are shorter than those in the neutral $18 \overline{\mathrm{e}}$ complexes 1a-d by ca. $0.04 \AA$, reflecting the presence of the positive charge, but longer (by $0.05-0.08 \AA$ ) than in the $16 \bar{e}$ complexes $\mathbf{2 a - d}$, in which they are strengthened by $\pi$-donation from the NPN-ligand. The chelate N1-Ru-N2 angles in $\mathbf{3 a}$ and $\mathbf{3 d}$ are similar to those of the other $18 \overline{\mathrm{e}} \mathrm{NPN}-$ complexes 1a-d. However, unlike in the related chloride complexes $\mathbf{1 a}$ and $\mathbf{1 d}$, the $\mathrm{Ru}-\mathrm{N} 1-\mathrm{P}-\mathrm{N} 2$ metallacycles in $\mathbf{3} \mathbf{a}$ and $\mathbf{3 d}$ are folded by $13-15.6^{\circ}$ from planarity at the $\mathrm{N} 1 \cdots \mathrm{N} 2$ hinge and the nitrogen atoms (N1 in 3a; N1 and N2 in 3d) are noticeably pyramidalized as shown by the $\Sigma(\mathrm{N})$ parameter. There are several close $\mathrm{H} \cdots \mathrm{F}$ contacts between the cation and the $\mathrm{PF}_{6}{ }^{-}$anion in both structures, although none of these is shorter than the sum of the van der Waals radii of $\mathrm{H}$ and $\mathrm{F}(2.56 \AA)$. ${ }^{23]}$

Complexes $\mathbf{3 a}$ and $\mathbf{3 d}$ are sufficiently stable in concentrated solutions to allow recording their NMR spectra, although the fraction of the corresponding $16 \bar{e}$ complexes increases with time. The ${ }^{31} \mathrm{P}$ NMR resonance ( $\delta 61.7$ for $3 \mathbf{a}$ and $\delta 60.2$ for $3 \mathbf{d}$ ) is downfield shifted by ca. $10 \mathrm{ppm}$ relative to the corresponding $16 \overline{\mathrm{e}}$ cationic complexes $\mathbf{2 a}$ and $\mathbf{2 d}$. In the ${ }^{1} \mathrm{H}$ and ${ }^{13} \mathrm{C}\left\{{ }^{1} \mathrm{H}\right\}$ NMR spectra recorded in $\mathrm{CDCl}_{3}$ there are two sets of signals for the magnetically inequivalent phenyl groups at the phosphorus atom, as expected for the $C_{s}$-symmetric complexes, hence the decoordination of $\mathrm{CO}$ is a slow process with a relatively high activation barrier. The resonance of the coordinated CO ligand in the ${ }^{13} \mathrm{C}$ NMR spectra is observed at high field $(\delta 199.2,193.8)$, as is typical of terminal linear coordinated CO ligands (cf. to $\delta 197.8$ for $4^{[17]}$ and $\delta$ 203-208 reported for the cyclopentadienyl ruthenium complexes with $\mathrm{N}, \mathrm{N}$-ligands)..$^{[9,24]}$

Both carbonyl adducts $\mathbf{3 a}$ and $\mathbf{3 d}$ exhibit strong $\mathrm{CO}$ stretching vibration band in the IR spectrum at $1984 \mathrm{~cm}^{-1}$ (3a) and $2012 \mathrm{~cm}$ ${ }^{1}$ (3d). The higher $v_{\mathrm{CO}}$ in $\mathbf{3 d}$ evidences weaker Ru-CO $\pi$-backbonding relative to $3 a$ that possesses the electron-richer $\mathrm{C}_{6} \mathrm{Me}_{6}$ arene. These frequencies are substantially lower than those of the more electron-deficient arene ruthenium amidinate carbonylic complex $\left[\left(\eta^{6}-\mathrm{C}_{6} \mathrm{H}_{6}\right) \mathrm{Ru}(\mathrm{CO})\left\{\mathrm{PhC}\left(\mathrm{N}^{t} \mathrm{Bu}\right)_{2}\right\}\right]\left(\mathrm{BAr}_{4}\right)\left(v_{\mathrm{CO}}=2050 \mathrm{~cm}\right.$ $\left.{ }^{1}\right),{ }^{[10]}$ but closer to those of the arene ruthenium complex with dianionic ditiolate ligands $4\left(v_{\mathrm{CO}}=1951 \mathrm{~cm}^{-1}\right){ }^{[17]}\left[\left(\eta^{6}-\right.\right.$ $\left.\left.\mathrm{C}_{6} \mathrm{Me}_{6}\right) \mathrm{Ru}(\mathrm{CO})(\mathrm{SXyl})_{2}\right] \quad\left(v_{\mathrm{CO}}=1965 \mathrm{~cm}^{-1}\right)^{[22]}$ and of the cyclopentadienyl complex with neutral $\kappa^{2}-\mathrm{N}, \mathrm{N}$-ligand $\left[\left(\eta^{5}-\right.\right.$ $\left.\left.\mathrm{C}_{5} \mathrm{H}_{5}\right) \mathrm{Ru}(\mathrm{CO})(\mathrm{TMEDA})\right]\left(\mathrm{BAr}_{4}\right)\left(v_{\mathrm{CO}}=1968 \mathrm{~cm}^{-1}\right) \cdot{ }^{[24]}$

Surprisingly, bubbling $\mathrm{CO}$ into the solution of $2 \mathrm{c}$ yielded a stable product, $3 \mathbf{c}$, resulting from the addition of two $\mathrm{CO}$ molecules, one of which has inserted into one of the two Ru-N bonds. The product has been fully characterized, including by single crystal X-ray diffractometry (Figure 11, Table S6 in ESI).

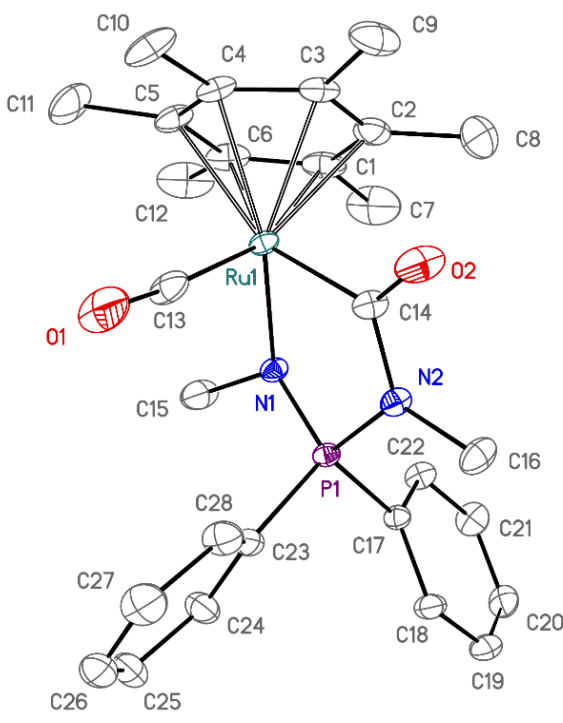

Figure 11. ORTEP diagram of the cation 3c. Ellipsoids are shown at $30 \%$ probability level. The hydrogen atoms and the anion are omitted for clarity. Selected bond lengths $(\AA)$ and angles $\left({ }^{\circ}\right)$ : Ru...Arene(centroid) 1.828(1), Ru$\mathrm{N} 12.107(2), \mathrm{Ru}-\mathrm{C}(\mathrm{O}) \mathrm{N} 2.042(3), \mathrm{C}=\mathrm{O} 1.211(4), \mathrm{N}-\mathrm{C}(\mathrm{O})$ 1.414(3), Ru-C(O) 1.859(3), C-O 1.143(4), N1-Ru-C(O) 83.15(10), $\quad \Sigma(\mathrm{N} 1) \quad 349.7(5), \quad \Sigma(\mathrm{N} 2)$ $359.3(6)$.

The overall geometry of $\mathbf{3 c}$ is similar to that of $\mathbf{3 a}, \mathbf{d}$ except for the expanded metallacycle with a $\mathrm{CO}$ group. The addition of two $\mathrm{CO}$ molecules leads to a significant increase of the $\mathrm{Ru}$ Arene(centroid) distance relative to $2 \mathrm{c}$ by ca. $0.18 \AA$ as a result of elongation of the $\mathrm{Ru}-\mathrm{C}$ (arene) bonds trans to the terminal $\mathrm{CO}$ (2.299-2.312(3) $\AA$ ) and to the carbamoyl $\mathrm{C}=\mathrm{O}$ group (2.3732.381(3) $\AA$ ). The arene $\mathrm{C}-\mathrm{C}$ bonds trans to the terminal $\mathrm{CO}$ $(1.404(6) \AA)$ and to $\mathrm{C}=\mathrm{O}$ group $(1.392(5) \AA$ ) are shorter than the other four bonds $(1.417-1.438(5) \AA)$. Similarly to 3a and 3d, the terminal carbonyl group is linear. The carbamoyl $\mathrm{C}=\mathrm{O}$ and $\mathrm{C}-\mathrm{N}$ bonds have similar length to or are slightly longer than those in organic amides. The carbamoyl N2 atom is planar, while N1 is considerably pyramidalized as in the corresponding $18 \overline{\mathrm{e}}$ chloride complex 1c. There are two intermolecular close contacts in the structure of $3 c$ that fall below the sum of the van der Waals radii, ${ }^{[23]}$ implicating hydrogen atoms of the $\mathrm{C}_{6} \mathrm{Me}_{6}$ ligand and either a $\mathrm{PF}_{6}{ }^{-} \mathrm{F}$ atom or the carbamoyl oxygen atom, $\mathrm{H}(8 \mathrm{~A}) \cdots \mathrm{F}(2.269 \AA)$ and $\mathrm{H}(10 \mathrm{~B}) \cdots \mathrm{O}(2) \mathrm{C}(2.418 \AA)$, respectively.

The ${ }^{13} \mathrm{C}\left\{{ }^{1} \mathrm{H}\right\}$ NMR spectrum of $3 \mathrm{c}$ reveals two signals corresponding to carbonyl C nuclei: a singlet at $\delta 198.2$ and a doublet at $\delta 192.8\left({ }^{2} J_{\mathrm{CP}}=19.6 \mathrm{~Hz}\right)$. All the $\mathrm{N}$ - and P-substituents in $\mathbf{3 c}$ are inequivalent and give rise to two sets of signals for both methyl and phenyl groups in the ${ }^{1} \mathrm{H}$ and ${ }^{13} \mathrm{C}\left\{{ }^{1} \mathrm{H}\right\}$ spectra. In the IR spectra 3c shows two strong carbonyl bands $v_{\mathrm{CO}}$ at $1984 \mathrm{~cm}^{-1}$ (metal bound $\mathrm{CO}$ ) and at $1644 \mathrm{~cm}^{-1}$ (carbamoyl $\mathrm{C}=\mathrm{O}$ ), the latter frequency being typical of organic amides.

Apparently, the carbonylation of $\mathbf{2 c}$ is a two-step reaction involving: 1) coordination of a first $\mathrm{CO}$ molecule to give an intermediate $\mathbf{C}$, which is structurally similar to $\mathbf{3 a}, \mathbf{d}$; and 2 ) 
insertion of the terminal $\mathrm{CO}$ into a $\mathrm{Ru}-\mathrm{N}$ bond and subsequent occupation of the resulting vacant site at the ruthenium atom by a second CO molecule (Scheme 4). This conclusion is further supported by the results of an IR spectroscopic monitoring at low temperatures (Fig. 12). Bubbling $\mathrm{CO}$ at $-40^{\circ} \mathrm{C}$ for $10 \mathrm{~s}$ fully converts $\mathbf{2 c}$ to an orange complex characterized by a strong $\mathrm{CO}$ band at $1975 \mathrm{~cm}^{-1}$, which can be attributed to the mono-adduct $\mathbf{C}$.
The latter is unstable: even at $-40^{\circ} \mathrm{C}$ and in the absence of additional $\mathrm{CO}$ it slowly disappears to be replaced by $3 \mathbf{c}$. The coordination of the first $\mathrm{CO}$ molecule is reversible, hence dissociation from the mono-adduct $\mathbf{C}$ provides the needed $\mathrm{CO}$ for the second carbonylation step. The rearrangement is complete within a few minutes at low temperatures and yields a 1:1 mixture of $\mathbf{2 c}$ and $\mathbf{3 c}$, which were isolated upon evaporation of the solvent.

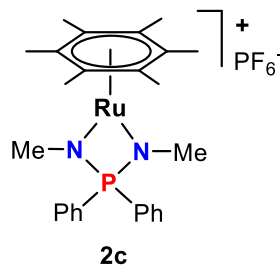

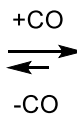

2c

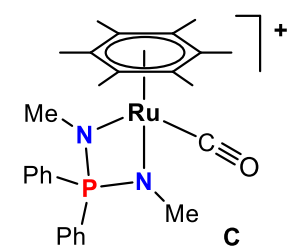

$v_{\mathrm{CO}}=1975 \mathrm{~cm}^{-1}$
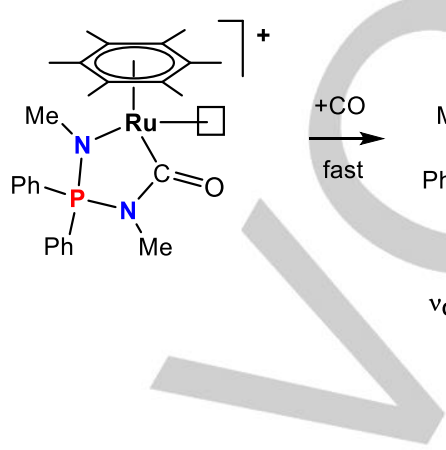

$\mathrm{C}-\mathrm{O}$ is $170.2^{\circ}$ ), and the $\mathrm{Ru}-\mathrm{CO}$ and $\mathrm{C}-\mathrm{O}$ bond lengths are 1.836 $\AA$ and $1.159 \AA$ A , respectively.

\section{Conclusions}

Our detailed spectroscopic study has allowed to investigate the stabilization of the coordinative unsaturation in half-sandwich ruthenium iminophosphonamide complexes depending on the $\mathrm{N}$-,P-substituents, arene and other co-ligands. By $2 \mathrm{D}$ EXSY ${ }^{1} \mathrm{H}$ NMR spectroscopy we have proven that the dynamic exchange process observed for chlorides 1a-d is attributed to the dissociation of the chloride ligand via a $16 \bar{e}$ intermediate in both polar and apolar solvents. The chloride dissociation enthalpy $\left(\Delta H_{d}\right)$ determined for the 18ē chloride complexes 1a-d and the $\mathrm{Cl}^{-}$ coordination enthalpy $\left(\Delta H_{c}\right)$ to the $16 \bar{e}$ complex $2 \mathrm{a}$ quantitatively estimate the stabilization effect of the NPN ligand, which is mostly provided by highly localized negative charges at the nitrogen atoms via additional $\pi$-donation. Hence the NPN ligands with Nalkyl groups destabilize the $18 \overline{\mathrm{e}}$ complexes and compensate the metal electron deficiency much more effectively than the NPN ligands with $\mathrm{N}$-aryl groups. Thus, the $\mathrm{N}$-Me chloride complex 1c dissociates exothermically $\left(\Delta H_{\mathrm{d}}=-5.0 \mathrm{kcal} / \mathrm{mol}\right)$ even in $\mathrm{CH}_{2} \mathrm{Cl}_{2}$, whereas the dissociation is always endothermic for the $\mathrm{N}$-Tol complexes (1a, $\mathbf{1 b}$ and $\mathbf{2 d}$ ), even in polar nitromethane. On the other hand, the less donating arene ligand ( $p$-cymene vs $\mathrm{C}_{6} \mathrm{Me}_{6}$ ) affects the stability of the $18 \overline{\mathrm{e}}$ complexes counterintuitively: it destabilizes the carbonyl adducts due to the lack of electron density provided for $\pi$-backdonation ( $\mathbf{3} \mathbf{d} v s \mathbf{3 a}$ ), but enhances the stability of the chloride complex (1d vs $\mathbf{1 a}$ ) due to lower energy of the orbital corresponding to $\mathrm{Ru}-\mathrm{Cl}$ bond. The coordination of ligands to $16 \bar{e}$ complexes $\mathbf{2}$ appears to be unambiguously exothermic, while the highly negative association entropy makes the $18 \bar{e}$ complexes stable only at low temperatures. Nevertheless, stronger $\pi$-acceptors $(\mathrm{CO}>$ pyridine $>\mathrm{MeCN}$ ) give more stable adducts due to significant contribution of $\pi$-backdonation to Ru-L bonding; this fact allowed us to isolate and structurally elongation of the $\mathrm{Ru}-\mathrm{C}$ (arene) bonds trans to $\mathrm{CO}$ and to the inserted carbene to $2.320-2.362 \AA$; the $C O$ ligand is linear $(R u-$ 
characterize complexes $\mathbf{3} \mathbf{a}$ and $\mathbf{3} \mathbf{d}$, which are rare examples of cationic $18 \overline{\mathrm{e}}$ arene ruthenium carbonyl complexes. The unexpectedly facile insertion of $\mathrm{CO}$ into the $\mathrm{Ru}-\mathrm{N}$ bond observed in the $18 \bar{e}$ adduct $\mathbf{2 c} \cdot \mathrm{CO}$ to give the carbonyl-carbamoyl complex $3 \mathbf{c}$ proves that arene ruthenium iminophosphonamide complexes can react in diverse manners and suggests that they have potential for application in organic synthesis and (bifunctional) catalysis. Further investigation of these complexes in catalytic transfer hydrogenation is in progress and will be reported soon.

\section{Experimental Section}

General procedures. All manipulations were carried out using standard Schlenk techniques under an atmosphere of dry argon. Absolute solvents were used for both synthesis and spectroscopic studies; solvents were purified by standard methods and distilled prior to use. The ${ }^{1} \mathrm{H},{ }^{31} \mathrm{P}$ and ${ }^{13} \mathrm{C}$ NMR spectra were obtained on Bruker Avance 600 or Bruker Avance 400 spectrometers and referenced to the residual signals of deuterated solvent $\left({ }^{1} \mathrm{H}\right.$ and $\left.{ }^{13} \mathrm{C}\right)$, and to $85 \% \mathrm{H}_{3} \mathrm{PO}_{4}\left({ }^{31} \mathrm{P}\right.$, external standard). The UV spectra were recorded on a Varian Cary 50 WinUV spectrometer in quartz cells (I $=2.2 \mathrm{~mm}$ or $10 \mathrm{~mm}$ ). The IR spectra were obtained on a Fourier spectrometer Nicolet 6700 in $\mathrm{KBr}$ cells $(I=0.514 \mathrm{~mm})$. The elemental analyses were carried out on a Carlo Erba $1106 \mathrm{CHN}$ analyzer. The following compounds were prepared according to described procedures: $\left[\left(\eta^{6}-p \text {-Cymene) } \mathrm{RuCl}_{2}\right]_{2},{ }^{[33]} \mathrm{Ph}_{2} \mathrm{P}(\mathrm{N}-p\right.$-Tol $)(\mathrm{NH}-p$-Tol $)(\mathbf{A}),{ }^{[15]}$ 1a-c, 2a-c. ${ }^{[15]}$

Synthesis of $\left[\left(\eta^{6}-p\right.\right.$-Cymene $\left.) \mathrm{RuCl}\left\{\mathrm{Ph}_{2} \mathrm{P}(\mathrm{N}-p-\mathrm{Tol})_{2}\right\}\right]$ (1d). To a solution of $\mathbf{A}(0.79 \mathrm{~g}, 2.00 \mathrm{mmol})$ in benzene $(60 \mathrm{~mL})$ a $2.0 \mathrm{M}$ solution of NaHMDS in THF $(1.10 \mathrm{~mL}, 2.20 \mathrm{mmol})$ was added and the resulting solution was stirred for $2 \mathrm{~h}$. Then solid [( $\eta^{6}-p$-Cymene $\left.) \mathrm{RuCl}_{2}\right]_{2}(0.61 \mathrm{~g}, 1.00 \mathrm{mmol})$ was added and the reaction mixture was stirred overnight. The reaction mixture was filtered and the solvent from the filtrate was removed under reduced pressure. The residue was washed with hexane $(2 \times 10 \mathrm{~mL}), \mathrm{Et}_{2} \mathrm{O}(2 \times 5 \mathrm{~mL})$, and then recrystallized from hot benzene $(20 \mathrm{ml})$. The dark-red crystalline was filtered off, washed with $\mathrm{Et}_{2} \mathrm{O}(5 \mathrm{~mL})$ and dried in vacuo. Yield $1.00 \mathrm{~g}$ (88\%). Anal. calcd for $\mathrm{C}_{36} \mathrm{H}_{38} \mathrm{CIN}_{2} \mathrm{PRu}$ : C, $64.90 ; \mathrm{H}, 5.75 \%$. Found: $\mathrm{C}$, 64.85; $\mathrm{H}, 5.84 \% .{ }^{31} \mathrm{P} \mathrm{NMR}\left(\mathrm{CDCl}_{3}\right): \delta 43.8\left(\mathrm{~s}, \mathrm{PPh}_{2}\right) .{ }^{1} \mathrm{H} \mathrm{NMR}\left(\mathrm{CDCl}_{3}\right): \delta$ $7.87\left(\mathrm{dd},{ }^{3} \mathrm{JHP}_{\mathrm{HP}}=10.8,{ }^{3} \mathrm{JHH}_{\mathrm{HH}}=8.0,4 \mathrm{H}, o-\mathrm{H}_{\mathrm{Ph}}\right), 7.50\left(\mathrm{~m}, 2 \mathrm{H}, p-\mathrm{HPh}_{\mathrm{Ph}}\right), 7.39(\mathrm{~m}$, $\left.4 \mathrm{H}, m-\mathrm{H}_{\mathrm{Ph}}\right), 6.90\left(\mathrm{~d},{ }^{3} \mathrm{H}_{\mathrm{HH}}=8.0,4 \mathrm{H}, \mathrm{C}_{6} \mathrm{H}_{4}(\mathrm{Tol})\right), 6.82\left(\mathrm{~d},{ }^{3} \mathrm{~J}_{\mathrm{HH}}=8.4,4 \mathrm{H}\right.$ $\left.\mathrm{C}_{6} \mathrm{H}_{4}(\mathrm{Tol})\right), 6.31\left(\mathrm{~d},{ }^{3} \mathrm{HHH}_{\mathrm{HH}}=5.6,2 \mathrm{H}, \mathrm{C}_{6} \mathrm{H}_{4}(\mathrm{Cym})\right), 5.41\left(\mathrm{~d},{ }^{3} \mathrm{JHH}_{\mathrm{HH}}=5.6,2 \mathrm{H}\right.$, $\mathrm{C}_{6} \mathrm{H}_{4}(\mathrm{Cym})$ ), 2.89 (sept, ${ }^{3} \mathrm{JHH}_{\mathrm{H}}=6.8,1 \mathrm{H}, \mathrm{CHMe}$ ), 2.19 (s, 6H, MeTol), 2.11 (s, 3H, Me $\mathrm{Cym}), 1.21\left(\mathrm{~d},{ }^{3} \mathrm{~J}_{\mathrm{HH}}=6.8,6 \mathrm{H}, \mathrm{CHMe}\right) .{ }^{31} \mathrm{P} \mathrm{NMR}\left(\mathrm{C}_{6} \mathrm{D}_{6}\right): \delta 42.9$. ${ }^{1} \mathrm{H}$ NMR $\left(\mathrm{C}_{6} \mathrm{D}_{6}\right): \delta 8.03\left(\mathrm{~m}, 4 \mathrm{H}, o-\mathrm{Hph}_{1}, 7.27\left(\mathrm{~d},{ }^{3} \mathrm{JHH}=7.8,4 \mathrm{H}, \mathrm{C}_{6} \mathrm{H}_{4}(\mathrm{Tol})\right)\right.$, $7.22(\mathrm{~m}, 3 \mathrm{H},(m+p)-\mathrm{Hph}), 6.93\left(\mathrm{~d},{ }^{3} \mathrm{HHH}_{\mathrm{H}}=7.8,4 \mathrm{H}, \mathrm{C}_{6} \mathrm{H}_{4}(\mathrm{Tol})\right), 6.75(\mathrm{~m}, 3 \mathrm{H}$, $\left.(m+p)-\mathrm{H}_{\mathrm{Ph}}\right), 5.05\left(\mathrm{~d},{ }^{3} \mathrm{JHH}_{\mathrm{H}}=6.0,2 \mathrm{H}, \mathrm{C}_{6} \mathrm{H}_{4}(\mathrm{Cym})\right), 4.87\left(\mathrm{~d},{ }^{3} \mathrm{JHH}_{\mathrm{HH}}=6.0,2 \mathrm{H}\right.$, $\left.\mathrm{C}_{6} \mathrm{H}_{4}(\mathrm{Cym})\right), 2.88$ (sept, $\left.{ }^{3} \mathrm{JHH}_{\mathrm{HH}}=6.6,1 \mathrm{H}, \mathrm{CHMe}\right), 2.15$ (s, 6H, Me $\left.\mathrm{Tol}_{\mathrm{Ol}}\right), 1.86$ $(\mathrm{s}, 3 \mathrm{H}, \mathrm{Me}$ cym $), 1.05\left(\mathrm{~d},{ }^{3} \mathrm{JHH}_{\mathrm{HH}}=6.8,6 \mathrm{H}, \mathrm{CHMe}\right) .{ }^{13} \mathrm{C} \mathrm{NMR}\left(\mathrm{CDCl}_{3}\right): \delta 145.8$ $\left(\mathrm{d},{ }^{2} J_{C P}=4.4, i-C_{\text {Tol }}(\mathrm{N})\right), 133.4$ (br.s, o-CPh), $131.9\left(\mathrm{~d},{ }^{4} \mathrm{JCP}_{\mathrm{CP}}=2.7, p\right.$-CPh $)$, 129.0 (s, $\left.\beta-\mathrm{CH}_{\mathrm{Tol}}\right), 128.2\left(\mathrm{~d},{ }^{3} \mathrm{JPP}_{\mathrm{CP}}=11.2, \mathrm{~m}-\mathrm{CPh}_{\mathrm{Ph}}\right), 127.5\left(\mathrm{~s}, i-\mathrm{C}_{\mathrm{TO}}(\mathrm{Me})\right)$, $122.9\left(\mathrm{~d},{ }^{3} J_{\mathrm{CP}}=9.7, \alpha-\mathrm{CH}_{\mathrm{Tol}}\right), 102.0\left(\mathrm{~s}, i-\mathrm{C}_{\mathrm{Cym}}\right), 94.8\left(\mathrm{~s}, i-\mathrm{C}_{\mathrm{Cym}}\right), 80.5$ (s, $\mathrm{CH}_{\text {cym }}$ ), 79.6 (s, $\mathrm{CH}_{\text {cym }}$ ), 30.9 (s, $\mathrm{CHMe}_{2}$ ), 22.5 (s, $\mathrm{CHMe}_{2}$ ), 20.5 (s, Me $18.9\left(\mathrm{~s}, \mathrm{Me}_{\mathrm{Cym}}\right) \cdot{ }^{13} \mathrm{C}$ NMR $\left(\mathrm{C}_{6} \mathrm{D}_{6}\right): \delta 146.9\left(\mathrm{~s},{ }^{2} \mathrm{~J}_{\mathrm{CP}}=4.2, i-\mathrm{C}_{\mathrm{To}}(\mathrm{N})\right), 136.5$ $\left(\mathrm{d},{ }^{1} J_{\mathrm{CP}}=95.1, i-\mathrm{CPh}_{\mathrm{Ph}}\right), 135.0\left(\mathrm{~d},{ }^{2} \mathrm{~J}_{\mathrm{CP}}=11.0, o-\mathrm{C}_{\mathrm{Ph}}\right), 132.6\left(\mathrm{~d},{ }^{2} J_{\mathrm{CP}}=9.8, o-\right.$ $\left.\mathrm{C}_{\mathrm{Ph}}\right), 132.0\left(\mathrm{~d},{ }^{4} \mathrm{~J}_{\mathrm{CP}}=2.7, p-\mathrm{C}_{\mathrm{Ph}}\right), 131.8\left(\mathrm{~d},{ }^{4} \mathrm{~J}_{\mathrm{CP}}=2.9, p-\mathrm{C}_{\mathrm{Ph}}\right), 130.2(\mathrm{~d}$, ${ }^{1} \mathrm{JPP}_{\mathrm{CP}}$ 84.0, $\left.i-\mathrm{CPh}_{\mathrm{Ph}}\right), 129.4\left(\mathrm{~s}, \beta-\mathrm{CH}_{\mathrm{Tol}}\right), 128.6\left(\mathrm{~d},{ }^{3} \mathrm{JCP}_{\mathrm{C}}=12.5, m-\mathrm{CPh}_{\mathrm{Ph}}\right), 128.5$ (s, $i$-C Tol $(\mathrm{Me})$ ), 127.7 (overlapped, $m$-C $\left.\mathrm{Ch}^{\prime}\right), 123.9\left(\mathrm{~d},{ }^{3} \mathrm{~J}_{\mathrm{CP}}=9.7, \alpha-\mathrm{CH}_{\mathrm{Tol}}\right)$, 102.4 (s, i- $\left.\mathrm{C}_{\text {cym }}\right), 94.8\left(\mathrm{~s}, i-\mathrm{C}_{\mathrm{cym}}\right), 80.7\left(\mathrm{~s}, \mathrm{CH}_{\mathrm{cym}}\right), 79.4\left(\mathrm{~s}, \mathrm{CH}_{\mathrm{cym}}\right), 31.2(\mathrm{~s}$, $\mathrm{CHMe}$ ), 22.5 (s, CHMe2), 20.7 (s, Metol), 18.8 (s, Mecym). UV-vis $\left(\mathrm{CH}_{2} \mathrm{Cl}_{2}\right.$; $\left.\lambda_{\max }, \mathrm{nm} ; \varepsilon, \mathrm{M}^{-1} \mathrm{~cm}^{-1}\right): 450$ ( 450 , shoulder).
Synthesis of $\left[\left(\eta^{6}-p-C y m e n e\right) R u\left\{P_{2} P(N-p-T o l)_{2}\right\}\right]\left(P_{6}\right) \quad(2 d)$. To a solution of $1 \mathrm{~d}(0.39 \mathrm{~g}, 0.59 \mathrm{mmol})$ in $\mathrm{CH}_{2} \mathrm{Cl}_{2}(15 \mathrm{ml})$, solid $\mathrm{AgPF}_{6}(0.16 \mathrm{~g}$, $0.62 \mathrm{mmol}$ ) was added, causing the color to immediately change from red to deep violet. The reaction mixture was stirred for $2 \mathrm{~h}$ and then filtered through a bed of Celite. The solvent was removed under reduced pressure, and the residue was dried in vacuo to give violet-black 2d. Yield $0.41 \mathrm{~g}$ (91\%). Anal. calcd for $\mathrm{C}_{36} \mathrm{H}_{38} \mathrm{~F}_{6} \mathrm{~N}_{2} \mathrm{P}_{2} \mathrm{Ru}$ : C, $55.74 ; \mathrm{H}, 4.94 \%$. Found: C, $55.47 ; \mathrm{H}, 4.99 \%$. ${ }^{31} \mathrm{P} \mathrm{NMR}\left(\mathrm{CDCl}_{3}\right): \delta 71.3$ (s, $\left.\mathrm{PPh}_{2}\right),-144.1$ (sept, JPF $=$ 712, $\left.\mathrm{PF}_{6}{ }^{-}\right) .{ }^{1} \mathrm{H}$ NMR $\left(\mathrm{CDCl}_{3}\right): \delta 7.65\left(\mathrm{~m}, 2 \mathrm{H}, p-\mathrm{HPh}_{\mathrm{Ph}}\right), 7.52\left(\mathrm{~m}, 4 \mathrm{H}, m-\mathrm{HPh}_{\mathrm{ph}}\right.$, $7.47\left(\mathrm{~m}, 4 \mathrm{H}, o-\mathrm{HPh}_{\mathrm{Ph}}\right), 7.02\left(\mathrm{~d},{ }^{3} \mathrm{JHH}_{\mathrm{HH}}=8.0,4 \mathrm{H}, \mathrm{C}_{6} \mathrm{H}_{4}\right), 6.84\left(\mathrm{dd},{ }^{3} \mathrm{JHH}_{\mathrm{HH}}=8.0\right.$, $\left.{ }^{4} J_{\mathrm{HP}}=1.2,4 \mathrm{H}, \mathrm{C}_{6} \mathrm{H}_{4}\right), 5.88\left(\mathrm{~d},{ }^{3} \mathrm{~J}_{\mathrm{HH}}=6.8,2 \mathrm{H}, \mathrm{C}_{6} \mathrm{H}_{4}(\mathrm{Cym})\right), 5.84\left(\mathrm{~d},{ }^{3} \mathrm{~J}_{\mathrm{HH}}=\right.$ 6.8, $\left.2 \mathrm{H}, \mathrm{C}_{6} \mathrm{H}_{4}(\mathrm{Cym})\right), 2.68\left(\mathrm{sept},{ }^{3} \mathrm{HHH}_{\mathrm{H}}=6.8,1 \mathrm{H}, \mathrm{CHMe}\right.$ ), $2.26(\mathrm{~s}, 3 \mathrm{H}$, Mecym), 2.25 (s, 6H, Meтo), 1.31 (d, $\left.{ }^{3} \mathrm{JHH}_{\mathrm{H}}=6.8,6 \mathrm{H}, \mathrm{CHMe}\right) .{ }^{13} \mathrm{C}$ NMR $\left(\mathrm{CDCl}_{3}\right): \delta 144.1\left(\mathrm{~d},{ }^{2} \mathrm{~J}_{\mathrm{CP}}=3.6, i-\mathrm{C}_{\mathrm{Tol}}(\mathrm{N})\right), 134.4\left(\mathrm{~d},{ }^{4} \mathrm{~J}_{\mathrm{CP}}=2.2, p-\mathrm{CPh}_{\mathrm{Ph}}\right), 134.1$ (s, $\left.i-\mathrm{C}_{\mathrm{Tol}}(\mathrm{Me})\right), 132.4\left(\mathrm{~d},{ }^{2} \mathrm{~J}_{\mathrm{CP}}=10.3, o-\mathrm{CPh}_{\mathrm{Ph}}\right), 130.2\left(\mathrm{~s}, \beta-\mathrm{CH}_{\mathrm{Tol}}\right), 129.5(\mathrm{~d}$, $\left.{ }^{3} J_{\mathrm{CP}}=12.5, m-\mathrm{CPh}\right), 124.7\left(\mathrm{~d},{ }^{1} \mathrm{JCP}=89.4, i-\mathrm{CPh}\right), 123.7\left(\mathrm{~d},{ }^{3} \mathrm{JCP}_{\mathrm{CP}}=8.0, \alpha\right.$ $\mathrm{CH}_{\text {Tol }}$ ), 99.6 (s, i-C Cym), 89.6 (s, $\left.i-\mathrm{C}_{\text {cym }}\right), 81.0\left(\mathrm{~s}, \mathrm{CH}_{\text {cym }}\right), 78.7$ (s, $\mathrm{CH}_{\text {cym }}$ ), 31.8 (s, $\mathrm{CHMe}_{2}$ ), 22.8 (s, $\mathrm{CHMe}_{2}$ ), 20.9 (s, Me $\left.\mathrm{Tol}\right), 19.7$ (s, Mecym). UV-vis $\left(\mathrm{CH}_{2} \mathrm{Cl}_{2} ; \lambda_{\max }, \mathrm{nm} ; \varepsilon, \mathrm{M}^{-1} \mathrm{~cm}^{-1}\right): 590$ (1880).

Reaction of $\mathbf{2 a}, \mathbf{2 c}, \mathbf{2 d}$ with $\mathrm{CO}$. General procedure. A stream of $\mathrm{CO}$ was slowly bubbled through a stirred solution of $2 \mathrm{a}(0.12 \mathrm{~g}, 0.15 \mathrm{mmol})$ in $\mathrm{CH}_{2} \mathrm{Cl}_{2}(5 \mathrm{~mL})$ for $10 \mathrm{~min}$. The color quickly changed from deep violet to orange. The product was precipitated with $\mathrm{Et}_{2} \mathrm{O}(20 \mathrm{ml})$ as a yellow-orange crystalline solid, which was filtered off and dried in vacuo for $1 \mathrm{hr}$. Yield $0.12 \mathrm{~g}(96 \%)$. Anal. calcd for $\mathrm{C}_{39} \mathrm{H}_{42} \mathrm{~F}_{6} \mathrm{~N}_{2} \mathrm{OP}_{2} \mathrm{Ru}$ : C, 56.32; $\mathrm{H}, 5.09 \%$. Found: C, 56.34; $\mathrm{H}, 4.95 \% .{ }^{31} \mathrm{P} \mathrm{NMR}\left(\mathrm{CD}_{2} \mathrm{Cl}_{2}\right): \delta 61.7\left(\mathrm{~s}, \mathrm{PPh}_{2}\right),-144.5$ (sept, $\left.{ }^{1} \mathrm{JPF}=713, \mathrm{PF}_{6}{ }^{-}\right) .{ }^{1} \mathrm{H} \mathrm{NMR}\left(\mathrm{CD}_{2} \mathrm{Cl}_{2}\right): \delta 7.84\left(\mathrm{t},{ }^{3} \mathrm{JHH}_{\mathrm{HH}}=8.6,1 \mathrm{H}, p-\mathrm{HPh}\right)$, $7.81\left(\mathrm{dd},{ }^{3} \mathrm{JHP}=12.8,{ }^{3} \mathrm{JHH}_{\mathrm{HH}}=8.0,2 \mathrm{H}, o-\mathrm{HPh}\right), 7.69\left(\mathrm{dt},{ }^{3} \mathrm{JHH}_{\mathrm{HH}}=7.2,{ }^{4} \mathrm{JPP}_{\mathrm{HP}}=3.2\right.$, $2 \mathrm{H}, m-\mathrm{Hph}), 7.48\left(\mathrm{dt},{ }^{3} \mathrm{JHH}_{\mathrm{HH}}=7.2,{ }^{5} \mathrm{JHP}=1.6,1 \mathrm{H}, p-\mathrm{HPh}\right), 7.24\left(\mathrm{dt},{ }^{3} \mathrm{JHH}_{\mathrm{HH}}=8.0\right.$, $\left.{ }^{4} \mathrm{JHP}_{\mathrm{HP}}=3.2,2 \mathrm{H}, m-\mathrm{HPh}^{\prime}\right), 7.19\left(\mathrm{dd},{ }^{3} \mathrm{JHP}=10.8,{ }^{3} \mathrm{JHH}_{\mathrm{HH}}=8.0,2 \mathrm{H}, o-\mathrm{HPh}^{\prime}\right), 6.90$ $\left(\mathrm{d},{ }^{3} \mathrm{~J}_{\mathrm{HH}}=8.0,4 \mathrm{H}, \mathrm{C}_{6} \mathrm{H}_{4}(\mathrm{Tol})\right), 6.46\left(\mathrm{dd},{ }^{3} \mathrm{~J}_{\mathrm{HH}}=8.0,{ }^{4} \mathrm{~J}_{\mathrm{HP}}=2.0,4 \mathrm{H}\right.$, $\left.\mathrm{C}_{6} \mathrm{H}_{4}(\mathrm{Tol})\right), 2.21$ (s, 6H, Me $\left.\mathrm{Tol}_{\mathrm{ol}}\right), 2.11\left(\mathrm{~s}, 18 \mathrm{H}, \mathrm{C}_{6} \mathrm{Me}_{6}\right) .{ }^{13} \mathrm{C} \mathrm{NMR}\left(\mathrm{CD}_{2} \mathrm{Cl}_{2}\right): \delta$ 199.2 (s, Ru-CO), $140.8\left(\mathrm{~d},{ }^{2} \mathrm{~J}_{\mathrm{CP}}=2.2, i-\mathrm{C}_{\mathrm{Tol}}(\mathrm{N})\right), 135.8\left(\mathrm{~d},{ }^{1} \mathrm{~J}_{\mathrm{CP}}=97.2, i-\right.$ CPh), $134.9\left(\mathrm{~d},{ }^{4} J_{\mathrm{CP}}=2.6, p-\mathrm{CPh}\right), 133.6\left(\mathrm{~d},{ }^{4} \mathrm{~J}_{\mathrm{CP}}=2.7, p-\mathrm{CPh}^{\prime}\right), 132.9(\mathrm{~d}$, $\left.{ }^{2} J_{\mathrm{CP}}=9.3, o-\mathrm{CPh}_{\mathrm{Ph}}\right), 132.7\left(\mathrm{~d},{ }^{2} \mathrm{~J}_{\mathrm{CP}}=11.0, o-\mathrm{CPh}_{\mathrm{Ph}}\right), 132.8\left(\mathrm{~s}, i-\mathrm{C}_{\mathrm{Tol}}(\mathrm{Me})\right), 130.4$ $\left(\mathrm{d},{ }^{4} \mathrm{~J}_{\mathrm{CP}}=1.3, \beta-\mathrm{CH}_{\mathrm{Tol}}\right), 130.0\left(\mathrm{~d},{ }^{3} \mathrm{~J}_{\mathrm{CP}}=12.1, \mathrm{~m}-\mathrm{C}_{\mathrm{Ph}}\right), 128.9\left(\mathrm{~d},{ }^{3} \mathrm{~J}_{\mathrm{CP}}=11.4\right.$, $m$-CPh'), $128.3\left(\mathrm{~d},{ }^{1} \mathrm{JCP}_{\mathrm{CP}} 83.3, i-\mathrm{CPh}^{\prime}\right), 126.0\left(\mathrm{~d},{ }^{3} \mathrm{JPP}=7.0, \alpha-\mathrm{CH}_{\mathrm{Tol}}\right), 110.3$ (s, $\mathrm{C}_{6} \mathrm{Me}_{6}$ ), 20.8 (s, Me $\left.\mathrm{Tol}_{\mathrm{To}}\right), 17.1$ (s, $\mathrm{C}_{6} \mathrm{Me}_{\underline{6}}$ ). UV-vis $\left(\mathrm{CH}_{2} \mathrm{Cl}_{2} ; \lambda_{\max }, \mathrm{nm} ; \varepsilon, \mathrm{M}^{-}\right.$ $\left.{ }_{1} \mathrm{~cm}^{-1}\right)$ : 450 (100, shoulder). IR $\left(\mathrm{CH}_{2} \mathrm{Cl}_{2}, v, \mathrm{~cm}^{-1}\right)$ : 1984 (RuCO).

Analogously, from 2c $(0.10 \mathrm{~g}, 0.15 \mathrm{mmol})$ in $\mathrm{CH}_{2} \mathrm{Cl}_{2}(3 \mathrm{ml})$, complex $3 \mathrm{c}$ was obtained as a stable yellow crystalline solid. Yield $0.10 \mathrm{~g}(95 \%)$. Anal. calcd for $\mathrm{C}_{28} \mathrm{H}_{34} \mathrm{~F}_{6} \mathrm{~N}_{2} \mathrm{O}_{2} \mathrm{P}_{2} \mathrm{Ru} \cdot \mathrm{H}_{2} \mathrm{O}: \mathrm{C}, 46.35 ; \mathrm{H}, 5.00 \%$. Found: $\mathrm{C}, 46.49 ; \mathrm{H}$, $5.00 \% .{ }^{31} \mathrm{P}$ NMR $\left(\mathrm{CD}_{2} \mathrm{Cl}_{2}\right): \delta 55.2\left(\mathrm{~s}, \mathrm{PPh}_{2}\right),-144.5\left(\mathrm{sept},{ }^{1} \mathrm{JPF}=713, \mathrm{PF}_{6}\right)^{-}$. ${ }^{1} \mathrm{H} \mathrm{NMR}\left(\mathrm{CD}_{2} \mathrm{Cl}_{2}\right): \delta 7.83\left(\mathrm{ttd},{ }^{3} \mathrm{JHH}_{\mathrm{HH}}=7.8,{ }^{4} \mathrm{~J}_{\mathrm{HH}}=1.8,{ }^{5} \mathrm{JPP}_{\mathrm{HP}}=1.2,1 \mathrm{H}, p-\mathrm{H}_{\mathrm{Ph}}\right)$, $7.75\left(\mathrm{ttd},{ }^{3} \mathrm{JHH}_{\mathrm{HH}}=7.8,{ }^{4} \mathrm{JHH}_{\mathrm{HH}}=1.2,{ }^{5} \mathrm{JHP}_{\mathrm{HP}}=1.2,1 \mathrm{H}, p-\mathrm{HPh}^{\prime}\right), 7.71\left(\mathrm{dt},{ }^{3} \mathrm{JHH}_{\mathrm{HH}}=7.8\right.$, $\left.{ }^{4} J_{\mathrm{HP}}=3.6,2 \mathrm{H}, m-\mathrm{HPh}\right), 7.63\left(\mathrm{ddd},{ }^{3} \mathrm{JPP}_{\mathrm{HP}}=12.6,{ }^{3} \mathrm{JHH}_{\mathrm{HH}}=7.8,{ }^{4} \mathrm{JHH}_{\mathrm{H}}=1.2,2 \mathrm{H}\right.$, $\left.o-H_{\mathrm{Ph}}\right), 7.60\left(\mathrm{dt},{ }^{3} J_{\mathrm{HH}}=7.8,{ }^{4} \mathrm{~J}_{\mathrm{HP}}=3.6,2 \mathrm{H}, m-\mathrm{H}_{\mathrm{Ph}}\right), 7.42\left(\mathrm{ddd},{ }^{3} \mathrm{JPP}_{\mathrm{HP}}=12.6\right.$, $\left.{ }^{3} J_{\mathrm{HH}}=7.8,{ }^{4} \mathrm{JHH}_{\mathrm{HH}}=1.2,2 \mathrm{H}, 0-\mathrm{HPh}^{\prime}\right), 2.73\left(\mathrm{~d},{ }^{3} \mathrm{JHP}_{\mathrm{HP}}=8.4,3 \mathrm{H}, \mathrm{NMe}(\mathrm{CO})\right), 2.64$ $\left(\mathrm{d},{ }^{3} \mathrm{JHP}_{\mathrm{HP}}=17.4,3 \mathrm{H}, \mathrm{NMe}\right), 2.24\left(\mathrm{~s}, 18 \mathrm{H}, \mathrm{C}_{6} \mathrm{Me}_{6}\right) \cdot{ }^{13} \mathrm{C} \mathrm{NMR}\left(\mathrm{CD}_{2} \mathrm{Cl}_{2}\right): \delta 198.2$ (s, Ru-CO), 192.8 (d, $\left.{ }^{2} J_{\mathrm{CP}}=19.6, \mathrm{NC}=\mathrm{O}\right), 135.1\left(\mathrm{~d},{ }^{4} \mathrm{JCP}_{\mathrm{CP}}=2.4, p-\mathrm{CPh}_{\text {) }}\right.$, $135.0\left(\mathrm{~d},{ }^{4} \mathrm{~J} \mathrm{CP}=2.4, p-\mathrm{CPh}^{\prime}\right), 133.6\left(\mathrm{~d},{ }^{2} \mathrm{JCP}_{\mathrm{CP}}=10.6, o-\mathrm{CPh}^{\prime}\right), 132.6\left(\mathrm{~d},{ }^{2} \mathrm{JCP}=\right.$ 10.6, o- $\left.\mathrm{CPh}_{\mathrm{Ph}}\right), 130.3\left(\mathrm{~d},{ }^{3} \mathrm{~J}_{\mathrm{CP}}=12.8, \mathrm{~m}-\mathrm{C}_{\mathrm{Ph}}\right), 130.2\left(\mathrm{~d},{ }^{3} \mathrm{~J}_{\mathrm{CP}}=12.6, \mathrm{~m}-\mathrm{C}_{\mathrm{Ph}}\right)$, $124.2\left(\mathrm{~d},{ }^{1} \mathrm{JCP}_{\mathrm{CP}}=112.2, i-\mathrm{CPh}\right), 122.2\left(\mathrm{~d},{ }^{1} \mathrm{JPP}_{\mathrm{CP}}=98.6, i-\mathrm{CPh}^{\prime}\right), 113.4(\mathrm{~s}, i$ $\mathrm{C}_{6} \mathrm{Me}_{6}$ ), $39.3\left(\mathrm{~d},{ }^{3} \mathrm{JCP}_{\mathrm{CP}} 4.2, \mathrm{NMe}\right), 29.3\left(\mathrm{~d},{ }^{3} \mathrm{~J}_{\mathrm{CP}}=8.4, \mathrm{NMe}(\mathrm{CO})\right), 17.0$ (s, $\left.\mathrm{C}_{6} \mathrm{Me}_{6}\right), . \mathrm{IR}\left(\mathrm{CH}_{2} \mathrm{Cl}_{2}, \mathrm{v}, \mathrm{cm}^{-1}\right)$ : $1983(\mathrm{RuCO}), 1644(\operatorname{RuC}(\mathrm{O}) \mathrm{N})$.

Analogously, carbonylation of $2 \mathrm{~d}(0.11 \mathrm{~g}, 0.14 \mathrm{mmol})$ gave a red solution of 3d. The product was precipitated by $\mathrm{Et}_{2} \mathrm{O}(20 \mathrm{ml})$ saturated with $\mathrm{CO}$, filtered and dried in vacuo for $30 \mathrm{~min}$. Yield $0.09 \mathrm{~g} \mathrm{(82 \% ).} \mathrm{Anal.} \mathrm{calcd} \mathrm{for}$ $\mathrm{C}_{37} \mathrm{H}_{38} \mathrm{~F}_{6} \mathrm{~N}_{2} \mathrm{OP}_{2} \mathrm{Ru}$ : C, 55.29; $\mathrm{H}, 4.77 \%$. Found: $\mathrm{C}, 55.05 ; \mathrm{H}, 4.86 \%$. ${ }^{31} \mathrm{P}$ $\operatorname{NMR}\left(\mathrm{CDCl}_{3}\right): \delta 60.2\left(\mathrm{~s}, \mathrm{PPh}_{2}\right),-144.2\left(\mathrm{sept},{ }^{1} \mathrm{JPF}=713, \mathrm{PF}_{6}{ }^{-}\right) .{ }^{1} \mathrm{H}$ NMR $\left(\mathrm{CDCl}_{3}\right): \delta 7.93\left(\mathrm{dd}^{3}{ }^{3} \mathrm{HP}=12.4,{ }^{3} \mathrm{JPP}_{\mathrm{HP}}=7.2,2 \mathrm{H}, \mathrm{o}-\mathrm{HPh}\right), 7.80\left(\mathrm{t},{ }^{3} \mathrm{JHH}=7.2\right.$ 
$\left.1 \mathrm{H}, p-\mathrm{HPh}_{\mathrm{Ph}}\right), 7.73\left(\mathrm{dt},{ }^{3} \mathrm{JHH}_{\mathrm{HH}}=7.6,{ }^{4} \mathrm{JHP}_{\mathrm{HP}}=2.8,2 \mathrm{H}, m-\mathrm{HPh}_{\mathrm{Ph}}\right), 7.50\left(\mathrm{t},{ }^{3} J_{\mathrm{HH}}=7.2\right.$ $\left.1 \mathrm{H}, p-\mathrm{H}_{\mathrm{Ph}}\right), 7.35\left(\mathrm{dd},{ }^{3} \mathrm{HHP}_{\mathrm{HP}}=10.2,{ }^{3} \mathrm{HHH}_{\mathrm{HH}}=7.2,2 \mathrm{H}, 0-\mathrm{HPh}^{\prime}\right), 7.30\left(\mathrm{dt},{ }^{3} \mathrm{HHH}_{\mathrm{HH}}=\right.$ $\left.7.6,{ }^{3} \mathrm{JHH}_{\mathrm{HH}}=3.2,2 \mathrm{H}, \mathrm{m}-\mathrm{HPh}^{\prime}\right), 6.87\left(\mathrm{~d},{ }^{3} \mathrm{~J}_{\mathrm{HH}}=8.0,4 \mathrm{H}, \mathrm{C}_{6} \mathrm{H}_{4}(\mathrm{Tol})\right), 6.51(\mathrm{~d}$, $\left.{ }^{3} \mathrm{JHH}_{\mathrm{HH}}=8.0,4 \mathrm{H}, \mathrm{C}_{6} \mathrm{H}_{4}(\mathrm{Tol})\right), 6.29$ (br. s, $\left.4 \mathrm{H}, \mathrm{C}_{6} \mathrm{H}_{4}(\mathrm{Cym})\right), 2.65$ (sept, ${ }^{3} \mathrm{JHH}_{\mathrm{HH}}=$ 6.8, $1 \mathrm{H}, \mathrm{CHMe}$ ), 2.18 (s, 6H, Meто), 2.11 (s, 3H, Meсуm), $1.22\left(\mathrm{~d},{ }^{3} \mathrm{JHH}=\right.$ 6.8, 6H, CHMe $).{ }^{13} \mathrm{C}$ NMR $\left(\mathrm{CDCl}_{3}\right): \delta 193.8$ (s, Ru-CO), 143.1 (d, ${ }^{2} \mathrm{~J} \mathrm{CP}=$ 3.4, $\left.i-\mathrm{C}_{\mathrm{To}}(\mathrm{N})\right), 134.5\left(\mathrm{~d},{ }^{4} \mathrm{~J}_{\mathrm{CP}}=2.6, p-\mathrm{CPh}_{\mathrm{Ph}}\right), 133.7\left(\mathrm{~d},{ }^{4} \mathrm{~J}_{\mathrm{CP}}=2.4, p-\mathrm{C}_{\mathrm{Ph}^{\prime}}\right)$, $132.7\left(\mathrm{~d},{ }^{2} \mathrm{JCP}_{\mathrm{CP}}=10.3, \mathrm{o}-\mathrm{CPh}\right), 132.2\left(\mathrm{~d},{ }^{2} \mathrm{JCP}_{\mathrm{CP}}=11.3, o-\mathrm{CPh}^{\prime}\right), 131.1\left(\mathrm{~d},{ }^{5} \mathrm{JCP}\right.$ $\left.=0.8, i-\mathrm{C}_{\text {Tol-Me }}\right), 130.0$ (s, $\left.\beta \square \mathrm{CH}_{\text {Tol }}\right), 129.9\left(\mathrm{~d},{ }^{3} \mathrm{~J}_{\mathrm{CP}}=12.3, m-\mathrm{CPh}_{\mathrm{Ph}}\right), 129.0(\mathrm{~d}$, $\left.{ }^{3} \mathrm{~J}_{\mathrm{CP}}=11.7, m-\mathrm{CPh}^{\prime}\right), 128.6\left(\mathrm{~d},{ }^{1} \mathrm{~J}_{\mathrm{CP}}=105.2, i-\mathrm{CPh}_{\mathrm{Ph}}\right), 126.8\left(\mathrm{~d},{ }^{1} \mathrm{~J}_{\mathrm{CP}}=80.6, i-\right.$ $\left.\mathrm{C}_{\mathrm{Ph}^{\prime}}\right), 123.4\left(\mathrm{~d},{ }^{3} \mathrm{~J}_{\mathrm{CP}}=8.6, \alpha-\mathrm{CH}_{\mathrm{Tol}}\right), 121.2\left(\mathrm{~s}, i-\mathrm{C}_{\mathrm{Cym}}\right), 119.5$ (s, $\left.i-\mathrm{C}_{\mathrm{Cym}}\right), 97.8$ (s, $\mathrm{CH}_{\text {cym }}$ ), 95.2 (s, $\mathrm{CH}_{\text {cym }}$ ), 32.1 (s, $\mathrm{CHMe}_{2}$ ), 22.7 (s, $\mathrm{CHMe}_{2}$ ), 20.6 (s, Мeто।), 19.5 (s, Mecym). IR ( $\left.\mathrm{CH}_{2} \mathrm{Cl}_{2}, v, \mathrm{~cm}^{-1}\right): 2012$ (RuCO). UV-vis $\left(\mathrm{CH}_{2} \mathrm{Cl}_{2}\right.$; $\left.\lambda_{\max }, \mathrm{nm} ; \varepsilon, \mathrm{M}^{-1} \mathrm{~cm}^{-1}\right): 480(140)$

EXSY ${ }^{1} \mathbf{H}$ NMR. 2D ${ }^{1} \mathrm{H}-{ }^{1} \mathrm{H}$ EXSY spectra were collected on a Bruker Avance 600 spectrometer at $25^{\circ} \mathrm{C}$ using the standard Bruker library noesygpph pulse program. At least three experiments with different values of the mixing time $t_{m}$ were performed to find an optimum mixing time, resulting in sufficiently large exchange cross-peaks without significant relaxation contribution. The rate constants $k=k_{\mathrm{AB}}+k_{\mathrm{BA}}$ for the $\mathrm{A} \leftrightarrow \mathrm{B}$ exchange reactions were calculated using simple two-site mode [19] using Equations (1), (2), where $k_{\mathrm{AB}}$ and $k_{\mathrm{BA}}$ are the rate constants of the direct and inverse reactions, $I_{\mathrm{AB}}, l_{\mathrm{BA}}$ and $I_{\mathrm{AA}}, l_{\mathrm{BB}}$ are the cross-peak and the diagonal peak integral intensities, respectively. In case of exchange between equally populated states $\left(k_{\mathrm{AB}}=k_{\mathrm{BA}}\right)$, the exchange rate constant is $k_{\mathrm{ex}}=k / 2$.

$k=\frac{1}{t_{m}} \ln \left(\frac{r+1}{r-1}\right)$

$r=\frac{I_{A A}+I_{B B}}{I_{A B}+I_{B A}}$

The activation free energy $\Delta G^{\ddagger}$ was calculated from the Eyring equation (3) and the activation enthalpy $\Delta H^{\ddagger}$ and entropy $\Delta S^{\ddagger}$ were derived by linear fitting of $R \ln \left(k_{\mathrm{ex}} / T\right)$ plotted $v s .1 / T$ according to the equation (4).

$\Delta G^{\neq}=-R T \ln \frac{k_{e x} h}{k_{b} T}$

$\boldsymbol{R} \ln \frac{k_{e x}}{T}=-\frac{\Delta H^{\ddagger}}{T}+\Delta S^{\neq}+R \ln \frac{k_{b}}{h}$

UV-Vis spectroscopic study. The UV-vis monitored titrations were performed in a $10 \mathrm{~mm}$ quartz cell, while the spectra at low temperatures were recorded in a $2.2 \mathrm{~mm}$ quartz cell. In most experiments the initial concentrations of ruthenium complex $\left(c^{0} \mathrm{Ru}\right)$ were $2.5 \times 10^{-3} \mathrm{M}$, while in other cases $c^{0}$ Ru was in the range $5-8 \times 10^{-4} \mathrm{M}$. Neat $\mathrm{MeCN}$ and pyridine were used for the titrations. To calculate the dissociation constants $K_{d}$ for $\mathbf{1 b}, \mathbf{c}$ (Eq. 5) and the constant $K_{\mathrm{c}}$ for the ligand coordination to 2a (Eq. 6), the equilibrium concentrations of the $16 \overline{\mathrm{e}}\left(\boldsymbol{c}_{16 \overline{\mathrm{e}}}\right)$ and $18 \overline{\mathrm{e}}\left(\boldsymbol{c}_{18 \mathrm{e}}\right)$ complexes were obtained from the UV-vis spectra according to the Beer-Lambert law. The absorption of the equilibrium mixture $D\left(\lambda_{i}\right)$ was measured at a wavelength $\lambda_{i}$ (Eq. 7), at which the absorption coefficient $\varepsilon_{18 \bar{e}}$ for $18 \bar{e}$ complexes ( 1 or $2 \mathrm{a}(\mathrm{L}))$ is close to zero, while the $\varepsilon_{16 \bar{e}}$ for $16 \overline{\mathrm{e}}$ species (2a-c) is still high enough. Particularly, at the chosen $\lambda_{\mathrm{i}}=600 \mathrm{~nm}, \varepsilon_{16 \mathrm{e}}$ is in the range $550-$ $650 \mathrm{M}^{-1} \mathrm{~cm}^{-1}$, whereas $\varepsilon_{18 \mathrm{e}}$ is $<30 \mathrm{M}^{-1} \mathrm{~cm}^{-1}$. Therefore, the equilibrium concentration $\boldsymbol{c}_{16 \mathrm{e}}$ can be approximated as in Equation (8).

$$
\begin{aligned}
& K_{d}=\frac{c_{R u+} c_{C l-}}{c_{R u C l}} \\
& K_{c}=\frac{c_{R u L+}}{c_{R u+} c_{L}} \\
& D\left(\lambda_{i}\right)=\varepsilon_{16 \overline{\mathrm{e}}}\left(\lambda_{i}\right) c_{16 \overline{\mathrm{e}}} l+\varepsilon_{18 \overline{\mathrm{e}}}\left(\lambda_{i}\right) c_{18 \overline{\mathrm{e}}} l \\
& c_{16 \overline{\mathrm{e}}} \sim \frac{D\left(\lambda_{600)}\right.}{\varepsilon_{16 \overline{\mathrm{e}}\left(\lambda_{600}\right) l}}
\end{aligned}
$$

In the titration of $\mathbf{2} \mathbf{a}$ with $\mathrm{L}$, the initial concentrations $c^{0} 16 \overline{\mathrm{e}}$ of $\mathbf{2} \mathbf{a}$ for every $i-$ titration point was corrected for the dilution factor $\left(\boldsymbol{c}_{16 \mathrm{e}}^{\mathbf{0}}(\boldsymbol{i})\right)$ according to Equation (9).

$c_{16 \mathrm{e}}^{0}(i)=c_{16 \overline{\mathrm{e}}}^{0} \frac{V_{16 \overline{\mathrm{e}}}^{0}}{v_{16 \mathrm{e}}^{0}+V_{L}}$

where $V_{\mathbf{1 6 e}}^{\mathbf{0}}$ and $V_{L}$ are the initial volume of $\mathbf{2 a}$ solution and the added volume of $L$, correspondingly.

Computational details. The geometry optimizations were carried out with the PBE functional and def2-TZVP ${ }^{[34]}$ basis set for all atoms without any symmetry restrictions in the gas phase using the Gaussian09 package. ${ }^{[35]}$ The obtained stationary points were confirmed to have no imaginary frequencies. The orbital energies were computed with the $\mathrm{SMD}^{[36]}$ solvent model using the gas phase optimized geometry.

X-ray crystal structure determination. Single crystals 1d, 2d, 3a, 3c, 3d were obtained by slow diffusion of $\mathrm{Et}_{2} \mathrm{O}$ into $\mathrm{CH}_{2} \mathrm{Cl}_{2}$ solutions; in the case of $\mathbf{3 d}$ the solution was saturated with $\mathrm{CO}$. The data collection for samples 1d and $\mathbf{2 d}$ were performed on a Bruker APEX DUO diffractometer, and those for $\mathbf{3 a}, \mathbf{3 c}$ and $\mathbf{3 d}$ on a Bruker SMART APEX II diffractometer, both equipped with an Apex II CCD detector and operating with MoKa radiation $(\lambda=0.71073 \AA)$. Frames were integrated using the Bruker SAINT software package ${ }^{[37]}$ by a narrow-frame algorithm. A semiempirical absorption correction was applied with the SADABS ${ }^{[38]}$ program using the intensity data of equivalent reflections. The structures were solved with direct methods and refined by the full-matrix least-squares technique against $\mathrm{F}^{2}$ hkl in anisotropic approximation with the SHELX[39] software package. The positions of the hydrogen atoms were calculated, and all hydrogen atoms were refined using the riding model with $1.5 \mathrm{Ueq}(\mathrm{Cm})$ and 1.2Ueq $(\mathrm{Ci})$, where $\mathrm{Ueq}(\mathrm{Cm})$ and $1.2 \mathrm{Ueq}(\mathrm{Ci})$ are respectively the equivalent thermal parameters of methyl and all other carbon atoms to which corresponding $\mathrm{H}$ atoms are bonded. The structure of $1 \mathbf{d}$ contains an interstitial $\mathrm{CH}_{2} \mathrm{Cl}_{2}$ molecule, which is disordered about an inversion center. In the structure of $\mathbf{3} \mathbf{d}$ two crystallographically independent cations and anions are related by an approximate non-crystallographic inversion center. Detailed crystallographic information is given in Table 4. Crystallographic data have been deposited to the Cambridge Crystallographic Data Centre, CCDC numbers 1536180-1536184. Copies of the data can be obtained free of charge via http://www.ccdc.cam.ac.uk/data_request/cif, or by e-mailing data request@ccdc.cam.ac.uk, or by contacting The Cambridge Crystallographic Data Centre, 12 Union Road, Cambridge CB2 1EZ, UK; fax: $+44(0) 1223-336033$. 
Table 3. Crystal data and structure refinement parameters for $\mathbf{1 d}, \mathbf{2 d}, \mathbf{3 a}, \mathbf{3 c}, \mathbf{3 d}$

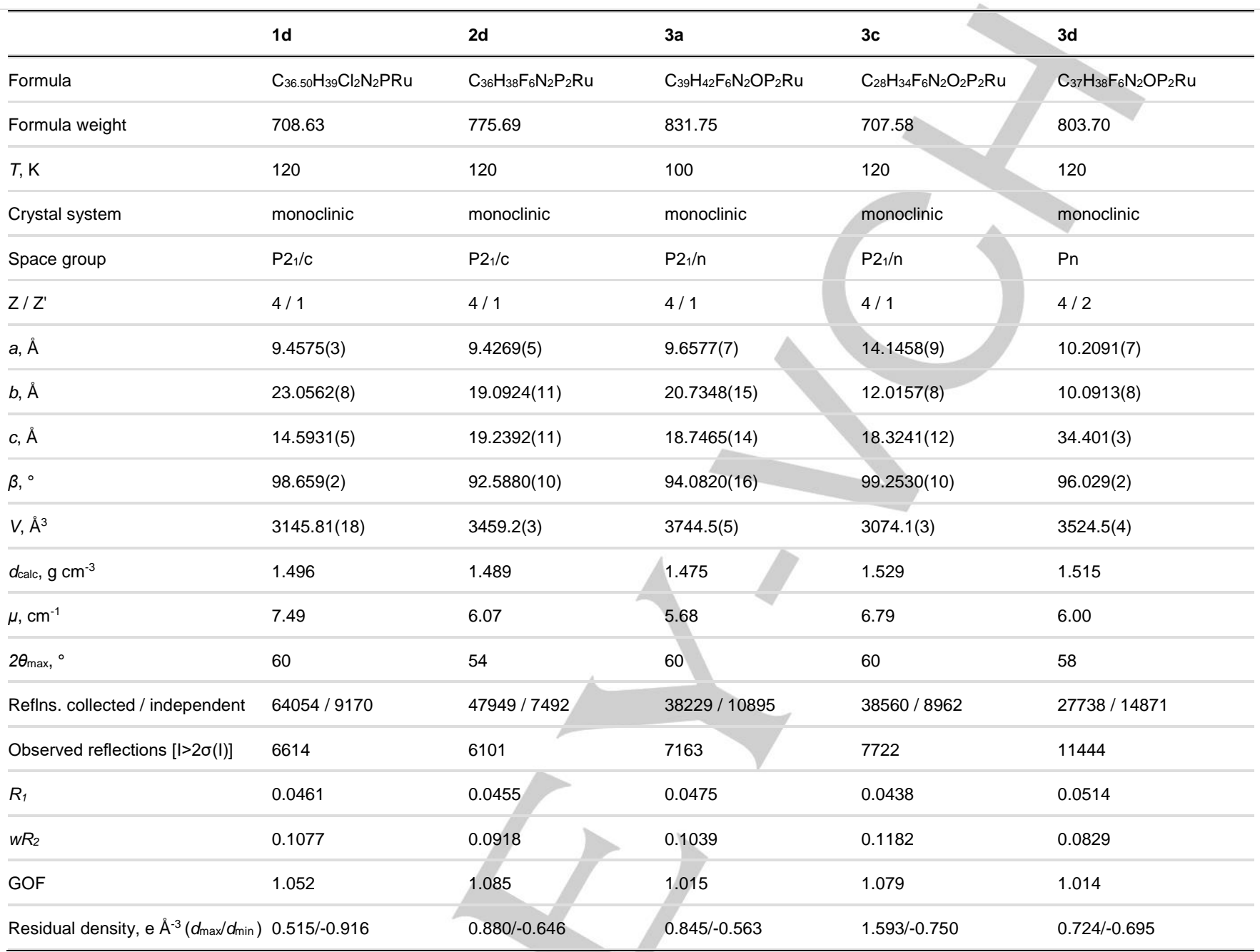

\section{Acknowledgements}

The authors thank the Russian Science Foundation (grant no. 1413-00801) for financial support. I.S. thanks the French Ministry of Foreign Affairs for a Ph.D. scholarship through the French Embassy in Moscow.

Keywords: ruthenium iminophosphonamides $\cdot$ electron-deficient complexes • carbonyl complexes $\bullet \mathrm{CO}$ insertion $\cdot 2 \mathrm{D}$ EXSY NMR

[1] T. Naota, H. Takaya, S.-I. Murahashi, Chem. Rev. 1998, 98, 25992660.

[2] R. Poli, Chem. Rev. 1996, 96, 2135-2204

[3] T.J. Johnson, K. Folting, W.E. Streib, J.D. Martin, J.C. Huffman, S.A. Jackson, O. Eisenstein, K.G. Caulton, Inorg. Chem. 1995, 34, 488-499.

[4] A.D. Phillips, G. Laurenczy, R. Scopelliti, P.J. Dyson, Organometallics 2007, 26, 1120-1122.

[5] A.D. Phillips, O. Zava, R. Scopelitti, A.A. Nazarov, P.J. Dyson, Organometallics 2010, 29, 417-427.

[6] A.D. Phillips, K. Thommes, R. Scopelliti, C. Gandolfi, M. Albrecht, K. Severin, D.F. Schreiber, P.J. Dyson, Organometallics 2011, 30, 6119-6132.
[7] P. Dejan, G. Thomas, B. Thomas, G.H. Cristian, R. Sören, G.J. Peter T. Matthias, Eur. J. Inorg. Chem. 2007, 3472-3475.

[8] T. Glöge, D. Petrovic, C. Hrib, P.G. Jones, M. Tamm, Eur. J. Inorg. Chem. 2009, 4538-4546.

[9] Y. Yamaguchi, H. Nagashima, Organometallics 2000, 19, 725-727. [10] T. Hayashida, Y. Yamaguchi, K. Kirchner, H. Nagashima, Chem. Lett 2001, 954-955.

[11] H. Kondo, Y. Yamaguchi, H. Nagashima, J. Am. Chem. Soc. 2001, 123, 500-501.

[12] H. Nagashima, H. Kondo, T. Hayashida, Y. Yamaguchi, M. Gondo, S. Masuda, K. Miyazaki, K. Matsubara, K. Kirchner, Coord. Chem. Rev. 2003 245, 177-190.

[13] J.I. Terasawa, H. Kondo, T. Matsumoto, K. Kirchner, Y. Motoyama, H. Nagashima, Organometallics 2005, 24, 2713-2721.

[14] T.A. Peganova, A.V. Valyaeva, A.M. Kalsin, P.V. Petrovskii, A.O. Borissova, K.A. Lyssenko, N.A. Ustynyuk, Organometallics 2009, 28, 30213028.

[15] T.A. Peganova, I.S. Sinopalnikova, A.S. Peregudov, I.V. Fedyanin, A. Demonceau, N.A. Ustynyuk, A.M. Kalsin, Dalton Trans. 2016, 45, 1703017041.

[16] P.J. Bailey, K.J. Grant, S. Parsons, Organometallics 1998, 17, 551-555.

[17] S. Tsukada, T. Sagawa, T. Gunji, Chem. Asian J. 2015, 10, 1881-1883.

[18] N.V. Belkova, L.M. Epstein, E.S. Shubina, Eur. J. Inorg. Chem. 2010, 3555-3565.

[19] A.D. Bain, Prog. Nucl. Magn. Reson. Spectrosc. 2003, 43, 63-103.

[20] C.L. Perrin, T.J. Dwyer, Chem. Rev. 1990, 90, 935-967.

[21] Although the Van't Hoff plot for 1d allowed us to find the entropy term $\Delta S=-18.7 \pm 0.4 \mathrm{cal} /(\mathrm{mol} \bullet \mathrm{K})$, it requires correction for chloride concentration. In 
fact it consists of $\Delta S_{\mathrm{ex}}{ }^{\neq}$and the constant $R \mathrm{In}\left[\mathrm{Cl}^{-}\right]$as the rate of associtive process depends on the concentration of the $\mathrm{Cl}^{-}$. Since the stationary $\left[\mathrm{Cl}^{-}\right]$is unknown the true $\Delta S_{\text {ex }}{ }^{\ddagger}$ cannot be calculated. Nevertheless, the calculated activation enthalpy $\Delta H_{\mathrm{ex}}{ }^{\ddagger}$ does not require any correction due to the change of the mechanism.

22] K. Mashima, H. Kaneyoshi, S.-I. Kaneko, A. Mikami, K. Tani, A. Nakamura, Organometallics 1997, 16, 1016-1025.

[23] R.S. Rowland, R. Taylor, J. Phys. Chem. 1996, 100, 7384-7391.

[24] C. Gemel, J.C. Huffman, K.G. Caulton, K. Mauthner, K. Kirchner, J. Organomet. Chem. 2000, 593-594, 342-353.

[25] A. Zamorano, N. Rendón, J.E.V. Valpuesta, E. Álvarez, E. Carmona, Inorg. Chem. 2015, 54, 6573-6581.

[26] C.J. Adams, R.A. Baber, N.G. Connelly, P. Harding, O.D. Hayward, M. Kandiah, A.G. Orpen, Dalton Trans. 2007, 1325-1333.

[27] C. Jones, C. Schulten, R.P. Rose, A. Stasch, S. Aldridge, W.D.

Woodul, K.S. Murray, B. Moubaraki, M. Brynda, G. La Macchia, L. Gagliardi, Angew. Chem. Int. Ed. 2009, 48, 7406-7410.

[28] T.J.J. Sciarone, C.A. Nijhuis, A. Meetsma, B. Hessen, Organometallics 2008, 27, 2058-2065.

[29] H. Brunner, J. Wachter, J. Chem. Res. (S) 1978, 136-137.

[30] E. Jellema, T.J.J. Sciarone, N.M. Navarrete, M.J. Hettinga, A

Meetsma, B. Hessen, Eur. J. Inorg. Chem., 2011, 91-100.

[31] Ö. Öztopcu, B. Stöger, K. Mereiter, K. Kirchner, J. Organomet. Chem. 2013, 735, 80-87.

[32] T. Hayashida, H. Nagashima, Organometallics 2001, 20, 4996-4998.

[33] S.B. Jensen, S.J. Rodger, M.D. Spicer, J. Organomet. Chem. 1998,

$556,151-158$.
[34] F. Weigend, R. Ahlrichs, Phys. Chem. Chem. Phys. 2005, 7, 32973305.

[35] M.J. Frisch, G.W. Trucks, H.B. Schlegel, G.E. Scuseria, M.A. Rob, J.R. Cheeseman, J.A.M. Jr, T. Vreven, K.N. Kudin, J.C. Burant, J.M. Millam, S.S. lyengar, J. Tomasi, V. Barone, B. Mennucci, M. Cossi, G. Scalmani, N. Rega,

G.A. Petersson, H. Nakatsuji, M. Hada, M. Ehara, K. Toyota, R. Fukuda, J. Hasegawa, M. Ishida, T. Nakajima, Y. Honda, O. Kitao, H. Nakai, M. Klene, X. Li, J.E. Knox, H.P. Hratchian, J.B. Cross, V. Bakken, C. Adamo, J. Jaramillo, R. Gomperts, R.E.Stratmann, O. Yazyev, A.J. Austin, R. Cammi, C. Pomelli, J.W. Ochterski, P.Y. Ayala, K. Morokuma, G.A. Voth, P. Salvador, J.J

Dannenberg, V.G. Zakrzewski, S. Dapprich, A.D. Daniels, M.C. Strain, O.

Farkas, D.K. Malick, A.D. Rabuck, K. Raghavachari, J.B. Foresman, J.V. Ortiz,

Q. Cui, A.G. Baboul, S. Clifford, J. Cioslowski, B.B. Stefanov, G. Liu, A.

Liashenko, P. Piskorz, I. Komaromi, R.L. Martin, D.J. Fox, T. Keith, M.A. AI-

Laham, C.Y. Peng, A. Nanayakkara, M. Challacombe, P.M.W. Gill, B.

Johnson, W. Chen, M.W. Wong, C. Gonzalez, J.A. Pople. Gaussian 09,

Revision D.01. Gaussian, Inc., Wallingford, CT, 2009, 2009.

[36] A.V. Marenich, C.J. Cramer, D.G. Truhlar, J. Phys. Chem. B 2009, 113 6378-6396.

[37] SAINT v8.34A., Bruker AXS, Madison, Wisconsin, USA, 2013.

[38] G.M. Sheldrick. SADABS, v. 2.03, Bruker/Siemens Area Detector

Absorption Correction Program, Bruker AXS, Madison, Wisconsin, 2003.

[39] G.M. Sheldrick, Acta Crystallogr. C 2015, C71, 3-8. 


\section{Entry for the Table of Contents}

\section{FULL PAPER}

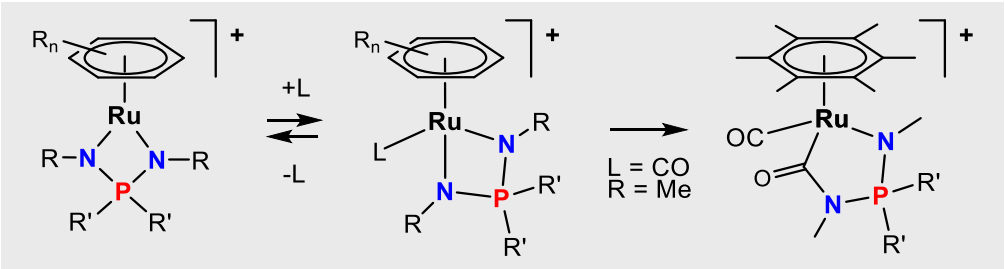

The lone pair of the highly basic iminophosphonamide $\mathrm{N}$-atoms in arene ruthenium complexes can both stabilize $16 \bar{e}$ species and attack an external ligand in $18 \bar{e}$ species. lana S. Sinopalnikova, Tat'yana A. Peganova, Valentin V. Novikov, Ivan V. Fedyanin, Oleg A. Filippov, Natalia V. Belkova, Elena S. Shubina, Rinaldo Poli, Alexander M. Kalsin*

Page No. - Page No.

Coordinatively labile 18-electron arene ruthenium iminophosphonamide complexes

Keywords: Arene ruthenium complexes, iminophosphonamides, electron-deficient compounds, N ligands, organometallic chemistry 